\title{
Práticas tecidas pela fé no cotidiano das devoções aos milagreiros em cemitérios do Ceará
}

\author{
Practices woven by faith \\ in the daily devotions to miracles in Ceará \\ cemeteries
}

\begin{abstract}
RESUMO
Este artigo enfoca a relação entre a morte e a formação da devoção a dois milagreiros em cemitérios do interior do Ceará. O primeiro é João Ferreira Gomes, conhecido popularmente como João das Pedras, o ladrão que roubava dos ricos para dar aos pobres, que morreu eletrocutado, em abril de 1978, quando tentava roubar uma casa na cidade de São Benedito. O segundo é o médico e ex-prefeito de Crateús, morto a facadas, em setembro de 1969, em decorrência da disputa por terras vizinhas ao sítio onde morava. A partir do recurso a entrevistas aos devotos e da análise de reportagens de jornais locais, busco compreender como a morte e fatos a ela ligadas, tais como a violência e o martírio, originaram e alimentam até hoje a devoção ainda praticada junto aos respectivos túmulos, transformando-os nos milagreiros do cemitério da localidade onde viveram. A partir do estudo desses casos, pretendo mostrar que a morte para estes sujeitos não significou o fim, mas o início de uma nova trama costurada pela fé nos milagres.
\end{abstract}

Palavras-chave: Martírios - Devoção - Milagreiros - Santos populares Devoção em cemitérios

\begin{abstract}
This article focuses on the relationship between death and the formation of devotion to two miracles in cemeteries in the interior of Ceará. The first is João Ferreira Gomes, popularly known as João das Pedras, the thief who stole from the rich to give to the poor, who died electrocuted in April 1978, when he tried to rob a house in the city of São Benedito. The second is the doctor and mayor of Crateús, stabbed to death in September 1969 due to the dispute over land near the place where he lived. From the use of interviews with devotees and the analysis of reports in local newspapers, I seek to understand how death and related facts, such as violence and martyrdom, originated and still feed today the devotion still practiced in the respective tombs, transforming them into the miracles of the cemetery in the locality where they lived. From the study of these cases, I intend to show that death for these subjects did not mean the end, but the beginning of a new plot stitched by faith in miracles.
\end{abstract}

Keywords: Martyrdom - Devotion - Miracles - Popular saints - Devotion in cemeteries

* Doutora em História pela Universidade Federal da Grande Dourados, Mato Grosso do Sul, Brasil. Professora dos cursos de Direito e de Arquitetura e Urbanismo do Centro Universitário UNINTA. No curso de Direito ministra a disciplina História do Direito e no curso de Arquitetura e Urbanismo ministra as disciplinas Estética e História da Arte, Humanidades Ciências Sociais e Cidadania. É Gestora de Pesquisa nessa mesma instituição. CV: http://lattes.cnpq.br/4057711169850301 


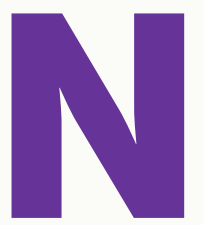

o presente artigo estudo a trajetória de construção de duas devoções populares desenvolvidas em cemitérios do interior do Ceará: a prestada a João das Pedras, no Cemitério municipal de São Benedito ${ }^{1}$, e a devoção ao doutor Olavo Cavalcante Cardoso, no Cemitério São Miguel, em Crateús². Investigo o surgimento das duas devoções, identificando a morte como principal elemento fundador e de que forma os cemitérios se tornaram o espaço escolhido pelos devotos para render as suas preces e promessas. Para esta análise, faço uso principalmente de entrevistas realizadas com devotos e contemporâneos dos dois milagreiros, entre 2002 e 2014 (ao longo do período em que desenvolvi minhas pesquisas de monografia de fim de curso, mestrado e doutorado), além de artigos de jornais locais e fotografias dos túmulos e locais de devoção.

A primeira devoção analisada é a prestada a João Ferreira Gomes, conhecido popularmente como João das Pedras, que morreu eletrocutado em abril de 1978, no Bairro Cruzeiro, na cidade de São Benedito. Ele era ladrão e a sua morte ocorreu durante a tentativa de roubar uma casa protegida por cerca elétrica de fabricação caseira. Após a morte, o corpo teria sido arrastado numa espécie de tábua de madeira até o centro da cidade. Esse ato foi considerado pelos entrevistados como uma "punição" atribuída naquele instante, ao ladrão, numa atitude que teria sido assistida e permitida por muitos dos que presenciaram 0 ato. Para alguns dos presentes, a morte foi considerada cruel e o cortejo do corpo visto como desrespeito ao morto. Desde então, João das Pedras está sepultado no Cemitério da cidade de São Benedito. Seu túmulo abriga ex-votos deixados pelos devotos, sendo o mais visitado do espaço.

A segunda devoção é ao doutor Olavo Cavalcante Cardoso, considerado milagreiro da cidade de Crateús. Morreu esfaqueado por agricultores, num conflito decorrente da disputa por terras da Fazenda Xavier, em setembro de 1969. A propriedade era de posse do médico e, segundo as entrevistas e jornais pesquisados, alguns vizinhos tentavam se apropriar de parte das terras que faziam fronteira com suas propriedades. $O$ homem que foi médico e prefeito da cidade era considerado humanitário e teria morrido sem socorro. Os assassinos se evadiram do local e apenas um foi preso. A morte do médico é interpretada como trágica e prematura, pois a vítima, segundo os entrevistados, não teria podido se defender do ataque de quatro agricultores armados com pás, enxadas e foices. Teria morrido clamando por socorro. Seu túmulo está localizado no Cemitério São Miguel, em Crateús, recebendo preces e pagamentos de promessas dos devotos. Em homenagem ao Dr. Olavo Cavalcante Cardoso, sua família construiu um cruzeiro no lugar onde morreu. Esse espaço também é visitado pelos devotos.

O estudo dessas duas devoções permite identificar os significados que a morte tem para os devotos, bem como a riqueza devocional da população local aos milagreiros dos cemitérios. Esses são vistos como espaços que conduzem os devotos para mais perto de seus intercessores, pois o túmulo é o lugar de onde se avista o milagre e o milagreiro. É também

1 A cidade de São Benedito dista aproximadamente $260 \mathrm{~km}$ de Fortaleza, capital do Ceará. Sua população segundo o censo de 2010 era de 44.178 habitantes e, para 2019, foi estimada em 47.903 habitantes. Disponível em: https:// cidades.ibge.gov.br/brasil/ce/sao-benedito/panorama

2 A cidade de Crateús está localizada na microrregião do Sertão dos Inhamuns, aproximadamente a $350 \mathrm{~km}$ de Fortaleza. Sua população, segundo o censo de 2010, era de 72.812 habitantes e, em 2019, foi estimada em 75.074 habitantes. Disponível em: https://cidades.ibge.gov.br/brasil/ce/crateus/panorama 
no cemitério que as memórias sobre a vida e a morte dos milagreiros são (re)elaboradas e a devoção fica mais evidenciada, demonstrando que para estes sujeitos a morte não significou o fim, mas o início de uma nova trama costurada pela fé nos Milagres.

As pesquisas sobre santos populares têm crescido nas últimas décadas. Marília Schneider aborda a devoção ao menino Antoninho da Rocha Marmo, de São Paulo, morto em decorrência de uma tuberculose, em 1930. Segundo a autora, houve incentivo familiar e de representantes do clero local no processo de surgimento da devoção e do culto ao menino, tendo como objetivo a sua beatificação (Schneider, 2001, p. 23). Esse aspecto me levou a observar a possibilidade de interferência da família do doutor Olavo Cavalcante Cardoso no processo de construção da sua devoção. A dissertação de lara Toscano Correia acerca da santidade de João Relojoeiro, cultuado em Uberaba, Minas Gerais, é um destes trabalhos. João Relojoeiro foi acusado, injustamente, de roubo, segundo seus devotos. Preso e torturado, ele teria morrido em decorrência da tortura sofrida em 1956. O estudo de Correia contribui para a nossa reflexão sobre a morte, o assassinato e os assassinos no processo de fabricação de milagreiros (Correia, 2003).

A impunidade dos culpados, tanto no caso do João Relojoeiro como na morte de João das Pedras e do Dr. Olavo Cavalcante Cardoso é uma característica que, associada à morte trágica e ao sofrimento, oferecem legitimidade à criação do milagreiro (Freitas, 2006, p. 6.). Vera Irene Jurkevics (2004, p. 16) analisou a devoção a Maria Bueno, a santinha de Curitiba, mulher pobre que foi semidegolada pelo amante, em 1893. Sua morte é um dos elementos centrais para aqueles que a consideram santa popular. Sandra Pesavento (2008, p. 345) enfocou o caso de Maria Degolada, assassinada em Porto Alegre pelo amante, um oficial da brigada militar. Para a autora, o seu assassinato e a morte trágica foram os principais elementos impulsionadores do culto a estas santas populares.

Uma das características destes estudos é a utilização da terminologia "santos populares". O conceito de popular surge da compreensão de que estes santos não foram oficializados pelo catolicismo oficial; ou seja, não compõem o panteão de devoções oficializadas pela beatificação ou canonização advindas da Igreja católica. Outra possibilidade de se entender o conceito devoção popular, é vislumbrar que são práticas da fé de sujeitos comuns, trabalhadores(as) de diversas áreas, aposentados, donas de casa, mães, mulheres e homens solteiros ou casados que dirigiram suas preces aos milagreiros para vencer as batalhas cotidianas em busca de saúde, emprego ou resolução de algum conflito.

Optei pelo uso da terminologia "milagreiros", palavra associada a milagres ou àquele que faz e concede milagres. Essa interpretação advém da pesquisa de campo e da análise das fontes. Isso não quer dizer que haja uma oposição entre milagreiros e santos populares, pois estão do mesmo lado, na categoria de popular. Apenas quis trazer para o texto o nome que mais apareceu durante a pesquisa, milagres, milagreiro, milagreiros. Tanto as promessas como a morte dos milagreiros foram a porta de entrada para entender como os sujeitos organizam no cotidiano a sua relação com o sagrado e o profano, o processo de pedir e pagar promessas. Carlos Rodrigues Brandão afirmou que estudar a religião nos possibilita compreender a cultura popular (Brandão, 1980, p. 15). Na devoção aos milagreiros, a luta percebida entre o erudito e 
o popular pode ser vislumbrada na sobrevivência das devoções, mesmo diante da reprovação do catolicismo oficial e as inúmeras de diversas formas com que este tenta desqualificar ou ignorar o que existe no cemitério, a exemplo da devoção ao João das Pedras, interpretada pelo clero local como uma prática decorrente da ignorância do povo.

A devoção aos milagreiros ocorre em demasia nos cemitérios e pode ser vislumbrada no dia 2 de novembro, dia de Finados, envolvendo não só a visita de familiares às necrópoles, como a dos devotos de modo geral. Uma explicação para o fato pode ser que, ao contrário das devoções aos santos oficiais, as relacionadas aos santos populares não possuem espaço próprio e data definida para a sua ocorrência, fazendo com que "o cemitério se converte em espaço ritual prioritário e popular" no dia de finados (Sáez, 1996, p. 146).

Nesse caso, a devoção na sepultura está associada ao antigo culto aos mártires, em suas sepulturas, no século V, como nos afirma Philippe Ariès (2003, p. 38). No início do Cristianismo, o culto aos santos mártires surgiu em volta de suas relíquias, junto às sepulturas (Sáez, 1996, p. 138). Entretanto, a devoção a santos populares não é restrita ao Cemitério. Eliane Tânia Martins de Freitas afirmou existir, no Brasil, um modesto juazeiro em cada cemitério de bairro, em cada cruz fincada numa beira de estrada onde morreu alguém de "má morte". São os santos dos populares, feitos, na maioria dos casos, pela piedade do povo. (Freitas, 2006, p. 14)

No que diz respeito aos milagreiros João das Pedras e Dr. Olavo Cardoso, a devoção ao primeiro é expressiva no Cemitério de São Benedito, enquanto a devoção prestada ao Dr. Olavo Cavalcante Cardoso se realiza em dois lugares: no seu túmulo e numa cruz erguida no lugar em que morreu. Em ambas as devoções, um dos pontos de semelhança é a compreensão da morte como trágica. Os ex-votos que expressam os pagamentos de promessas e são expostos no túmulo são as principais características que apresentam o milagreiro no cemitério para o público. Nos espaços de devoções, os ex-votos mais presentes são os de madeira, representando partes do corpo (cabeça, seios, pernas, braços, pescoço, mãos) e remetendo para a cura de uma doença. Além destes de madeira, podem ser visualizados outros ex-votos (fotografias, caixas de remédios, exames, fitas, garrafas com água, imagens de santos católicos), que sinalizam para pedidos diversos: de cura e saúde, de busca pela solução dos problemas terrenos, como desemprego, pagamento de dívidas, compra da casa própria dentre outras necessidades. Vejamos o surgimento de cada uma dessas devoções.

\section{João das Pedras: morte e devoção}

No Cemitério Municipal de São Benedito, João Ferreira Gomes, conhecido por João Pedras, recebe as homenagens e devoções. O sujeito era conhecido como o ladrão que "roubava dos ricos" para dar aos pobres, conforme relatos dos entrevistados. Estes relatos me possibilitaram seguir os fios da memória coletiva que foi e ainda é compartilhada na cidade. ${ }^{3}$

\footnotetext{
3 A memória coletiva, segundo Alessandro Portelli, deve ser compreendida como "todas as atividades humanas, a memória é social e pode ser compartilhada (razão pela qual cada indivíduo tem algo a contribuir para a história social); mas do mesmo modo que langue se opõe a parole, ela só se materializa nas reminiscências e nos discursos individuais. Ela só se torna memória coletiva quando é abstraída e separada da individual" (PORTELLI, 1998, p. 127).
} 
João das Pedras era o único filho de Maria Ferreira Gomes, que possuía outras quatro filhas. Era preto, pobre e morava na periferia de São Benedito, em meados de 1970. As irmãs, assim como a mãe, trabalhavam na agricultura e às vezes como domésticas na cidade. Segundo relato de Maria das Graças Marques, irmã de João das Pedras, o irmão começou a roubar na adolescência, "por culpa das más companhias", que o levou a se distanciar da família. ${ }^{4}$ Foi preso na cadeia municipal de São Benedito (não consegui precisar quantas vezes, devido à falta de documentação acerca das prisões), fugia e deixava a família sem notícias. Outras vezes, a casa era invadida por policiais a procura dos objetos roubados. Em várias situações, mãe e irmãs tinham dificuldade de conseguir emprego devido à fama de João. ${ }^{5} \mathrm{Se}$, para a família os roubos têm este significado de lástima e dor, para outros sujeitos de São Benedito, o sentido dos roubos era de "doar o que roubava para os pobres". Questão sempre mencionada nas entrevistas. Segundo Nilo Paula Santana, João das Pedras "não fazia nada com ninguém. (...) O povo sempre dizia que ele nunca matou ninguém (...) se a pessoa tinha necessidade, como essa velhinha que eu tô falando (...). [Ele] Chegou na casa dela. Vivia com fome e coisa e tal. Aí ele foi por ali, adquiriu um frango, adquiriu a farinha e veio deixar pra ela". 6

De fato, não encontrei nenhum registro na "oralidade sambeneditense" que indicasse, diretamente ou indiretamente, alguma agressão física cometida por João das Pedras contra alguém. Isso é defendido até por aqueles que compunham o quadro de policiais da delegacia de São Benedito. Francisco Arruda Maia, ex-policial, diz que João nunca foi preso por outro motivo que não fossem os furtos. ${ }^{7}$ Francisca Roberta afirmou que João das Pedras: "Nunca ele ofendeu ninguém, nunca ninguém ouviu falar que ele fizesse mal a moça nenhuma, e nem nada no mundo. Era só esse negócio que ele fazia: tirava de quem tinha e dar a quem não tinha". 8

Creio que se João das Pedras tivesse batido, assassinado alguém, ainda assim haveria especulações e uma suposta admiração, atraindo o interesse de alguns, pois há bandidos que, mesmo com a prática de crimes hediondos, são admirados, perdoados e compreendidos como heróis. Situação semelhante ocorreu na transformação mítica do cangaceiro Jararaca em herói, conforme estudo de Kesia Cristina França Alves. Segundo ela, os crimes praticados por Jararaca, que não perdoava nem mesmo as criancinhas, são sabidos pela população de Mossoró, no Ceará, inclusive entre aqueles que the dedicam a nomeação e fé de santo concessor. Um dos crimes mencionados nas entrevistas que realizou foi "quando ele teria matado uma criancinha aparando-a na ponta de um punhal". Ao invés de causar o repúdio, a morte da criança foi interpretada de outra forma, posto que ele teria se arrependido dos crimes. Para Alves, "a história que respalda o arrependimento relata apenas um crime do qual

4 Entrevista realizada pela autora a Maria das Graças Marques Gomes, 53 anos, dona de casa, no dia 12/02/2005, em sua residência, no sítio Pimenteira, em São Benedito.

5 Entrevista realizada pela autora a Raimunda Marques, agricultora, casada, irmã de João das Pedras, no dia 12/02/2004, em sua residência no sítio Baixa Grande.

6 Entrevista realizada pela autora a Nilo Paula Santana, 76 anos, aposentado, no dia 03/04/2004, em sua residência, no sítio Pombal, em São Benedito.

7 Entrevista realizada pela autora a Francisco Arruda Maia, policial militar aposentado, de 64 anos, em 09/05/2005, na sua residência no bairro Papicu, Fortaleza, Ceará. É chamado de sargento Maia por muitos, em São Benedito.

8 Entrevista realizada pela autora a Francisca Roberta da Silva, aposentada, 54 anos, no dia 19/03/2004, em sua residência na Rodovia da Confiança Norte em São Benedito. 
o bandido teria se arrependido" foi justamente o da morte dessa criança. Segundo a autora, no ideário popular não era necessário não ter cometido o crime, bastando ter se dele se arrependido (Alves, 2006, p. 93).

Com isso, quero dizer que o fato de João das Pedras ter preservado a vida das vítimas de seus roubos pode ter contribuído para ele ser enaltecido como um "bom ladrão". Não ter seduzido ou violentado nenhuma "moça" também o tornou virtuoso aos olhos de muitos. A sua morte corroborou para que seus atos fossem vistos pelo olhar da bondade de quem os interpreta. Entretanto, durante toda a pesquisa, nunca entrevistei alguém que tivesse, de forma direta, recebido uma "ajuda" e "auxílio" de João. É como se estas pessoas tivessem deixado de existir no real, no cotidiano, para serem realidades mencionadas no plano narrativo, sem nome e sem endereço. É sempre alguém que ouviu falar de alguém. Nenhum dos meus entrevistados foi "beneficiado" por um furto. Os vitimados pelos furtos de João também passam por este desconhecimento, salvo em poucos casos. Os roubos para o bem dos pobres não perdem seu significado e são apresentados nos jogos das oralidades cotidianas, compondo uma rede de mitos (Maia, 2010).

Para Carlo Ginzburg, o mito pode ser "veículo de afirmações falsas" (2001, p. 4246). Esta afirmação me leva a interpretar relatos dos entrevistados sobre o João das Pedras como vestígios de um processo de construção tanto do mito relacionado aos roubos por ele praticados como também do que envolve suas fugas como veículos de afirmações verdadeiras sobre o ladrão. Uma verdade narrada com suas outras verdades, também relativas pelo prisma de cada um. Para Maria Aparecida Carvalho: "Sempre as histórias que eu ouvia falar dele sempre eram uma história bonita. Não tinha história triste de ele matar ninguém, fazer mal a ninguém. Era uma pessoa que, que roubava para ajudar". ${ }^{9}$

Não encontrei documentos escritos ou jornais sobre qualquer fragmento da vida ou morte do João das Pedras. Até boletins de ocorrência sobre as suas prisões em São Benedito foram perdidos pelo tempo, pois os arquivos da delegacia municipal referentes à década de 1970 não foram encontrados. No Cartório Amaral do 2 Ofício não existe sua certidão de óbito. Questionada sobre o fato, sua mãe afirmou que não tinha solicitado certidão de óbito porque João das Pedras era "um ladrão" e, segundo ela, ele não possuía direito a esse documento. Ou seja, para ela, mesmo após a morte, João das Pedras continuava a ser um bandido (Maia, 2010). Consultando os livros de memorialistas locais, verifiquei que tampouco há registros sobre a morte ou a devoção criada a João das Pedras nas obras de José Hudson Brandão (2002) e de Maria Stella Furtado (2005). Da mesma forma, seja no cartório ou na prefeitura municipal (responsável pela administração do cemitério da cidade), não encontrei nenhuma documentação.

João das Pedras não sabia ler nem escrever e, segundo sua mãe, nem ele nem suas irmãs estudaram, pois tinham que trabalhar. ${ }^{10}$ Por este motivo, não pude fazer uso da trajetória escolar de João das Pedras. Maria Ferreira Gomes não lembra a data de nascimento ou morte

9 Entrevista realizada pela autora a Maria Aparecida de Matos Carvalho, 53 anos, agente de saúde, em 07/03/2005, em sua residência, na Rodovia da Confiança Norte, em São Benedito.

10 Entrevista realizada pela autora a Maria Ferreira Gomes, aposentada, 64 anos, em 01/06/2003, em sua residência, no Sítio Pimenteira, em São Benedito. 
do filho. Os registros se perderam com o tempo (Maia, 2010). Na pesquisa ao hebdomadário católico, Correio da Semana, ${ }^{11}$ jornal de circulação em Sobral, Ceará, investiguei as décadas de 1960 e 1970, mas não há nota alguma sobre qualquer assunto relacionado a João das Pedras que, ao que parece, conseguiu sobreviver às armadilhas do esquecimento através da sua imagem de milagreiro. As histórias sobre sua vida, morte e milagres estão na memória de alguns habitantes de São Benedito. Nos arredores da cidade de São Benedito, João das Pedras é capturado "pelo falar" e "pelo ouvir dizer". João é um fantasma falado, uma ausência presente, um morto que age nas preces dos devotos. Uma presença feita pela fé e pela devoção a ele prestada. Se é a morte que nos permite saber mais sobre ele e sobre o início da construção de sua "santidade", vejamos um pouco mais sobre ela.

Ele morreu eletrocutado em abril de 1978, no Bairro do Cruzeiro em São Benedito, ao tentar roubar uma casa com uma cerca elétrica de fabricação caseira. A casa em questão era de Epifânio Rodrigues, pai do Padre João Batista. ${ }^{12}$ A fiação teria sido preparada, segundo o próprio Padre João Batista, porque João das Pedras havia tentado entrar na residência no dia anterior. Fato que, para alguns entrevistados, seria o indicio de uma "armadilha" e da intencionalidade de matá-lo, porque foi direcionada a ele infrator Segundo Francisca Muniz: "fizeram esta armadilha porque ele já tinha entrado uma das vezes, então eles fizeram armadilha pra pegar, pra saber quem era. [...] Mas, se eles fizeram essa armadilha, foi com mau intenção [...] mas eu não gostei nem um pouco, eu acho que foi feito com maldade". ${ }^{13}$ Não houve nenhum inquérito policial para apurar as circunstâncias da morte de João das Pedras. O que, para os devotos significou impunidade aos responsáveis por sua morte, embora para outros tivesse sido ato de defesa da propriedade.

A cada relato da morte observamos que a culpa de João das Pedras pela tentativa de roubo não foi colocada no centro das narrativas dos entrevistados. $O$ fato de ter morrido no local me fez questionar se sua morte teria a repercussão que teve caso tivesse ocorrido por causas naturais. Até que ponto teria se transformado em milagreiro? De culpado, João das Pedras passou a ser considerado vítima nas narrativas de seus devotos, conforme afirma Milliet: "o culpado torna-se vítima, o condenado, mártir" (2001, p. 11-14).

Além desse aspecto, outro teria contribuído para a transformação da culpa em martírio. Também associada à sua morte, tratou-se da forma como seu cadáver teria sido carregado do local da morte para o centro da cidade: carregado em uma espécie de tábua de madeira, tendo pés e mãos amarrados, como se tivessem a intenção de aplicar uma "punição pública" ao ladrão. Os nomes dos carregadores não aparecem nos relatos, o que nos faz crer que o anonimato decorre por serem conhecidos e estarem ainda vivos. Este ato foi considerado como profanação do corpo, como podemos exemplificar no relato de Luiz Antonio de Sousa:

11 Semanário católico organizado pela Diocese de Sobral, o Correio da Semana teve sua primeira publicação no ano de 1918. Pesquisei os exemplares da década de 1970 no próprio arquivo do Correio da Semana localizado na Rua Ernesto José Pedro, 710 em Sobral, Ceará.

12 Entrevista realizada pela autora a João Batista Rodrigues, 38 anos, sacerdote, no dia 02/10/2005, na secretaria paroquial de São Benedito.

13 Entrevista realizada pela autora a Francisca Muniz do Nascimento, 81 anos, aposentada, no dia 01/05/2005, em sua residência na rua Deputado Vicente Ribeiro, em São Benedito. 
Eu me deparei com o povo amarrando ele, é, tipo como se amarra um animal pra trazer, um porco, uma coisa. Vindo de lá pra cá, o povo vinha fazendo aquele barulho, por ele ser, ele era ladrão, e aí o pessoal esculhambava ele, dizia palavrão, zombava, era mais zomba mesmo. Dizia: - Aonde é que tu ainda vai roubar? Tu ainda vai roubar? ${ }^{14}$

Mesmo entre aqueles que não aprovam a devoção a João das Pedras como milagreiro houve a interpretação de que o corpo morto foi desrespeitado. No relato do Padre João Batista (proprietário da casa que seria invadida por João das Pedras ao ser eletrocutado), esta cena foi assistida e legitimada por muitos:

A forma como ele foi trazido, talvez isso foi muito desagradável para muitas pessoas. No momento a minha mãe não tinha reações. Porque nunca tinha acontecido isso em casa e ela ficou no quarto desesperada. Então, quando chegaram, alguém que conheceram, essas pessoas foram muito hostis, muito brutas em dizer:

- Não, leva de qualquer jeito!

- É, é um ladrão!

Você tá entendendo? Alguém sugeriu: podia vir até arrastando, e então pegaram, pegaram acho que foi um pau, uma coisa lá e impiduraram [pendurado] as duas mãos e os pés e trouxeram ele impidurado [pendurado]. Quer dizer: ninguém, ninguém teve ação de pedir uma rede e nem ninguém teve ação de oferecer uma rede aqui na rua, na nossa rua, e cheio de gente. Foi a vinda cruel? Foi, né. Foi desagradável, não é? Talvez, foi até desumano, né. Mas, naquele momento, foi motivado por muita gente não que a pessoa ia ceder por isso também, não é? Mas foi por muita gente: que não precisava, que podia trazer de qualquer jeito, era um ladrão! Inclusive o pessoal do seu, na época o pai do Antonio Glória, seu Glória, acho que ele tomava parte de alguma função de justiça. Ele mesmo foi o próprio a dizer:

- Não, leva de qualquer jeito, é o João das Pedras. Todo mundo tinha vontade que esse cara morresse, que desse um fim a ele.

Quer dizer essa ação do povo, apesar de desumana, mas foi aplauso. ${ }^{15}$

João das Pedras tinha aproximadamente 35 anos quando da tentativa de roubar uma casa. Para muitos, o ladrão teve o destino final que merecia e tudo que ocorreu ao seu corpo teria sido natural. Para outros, entretanto, a morte foi considerada cruel, uma armadilha, uma morte prematura e sem defesa à "vítima". O cortejo pelas ruas do centro da cidade expôs a profanação do corpo: amarrado depois de morto, todos estes elementos na trajetória do João das Pedras são os principais indícios que anunciam para os devotos que os seus pecados teriam sido perdoados:

Trouxeram ele, amarraram as mãos e os pés e enfiaram num pau, trouxeram como quem traz um animal. E, então, todo mundo ficou muito revoltado que não podia ser daquele jeito. Podia ter botado numa

14 Entrevista realizada pela autora a Luiz Antonio Sousa, 37 anos, professor de História do Colégio Ministro Antonio Coelho, dia 02/11/2004, no cemitério de São Benedito.

15 Entrevista realizada pela autora ao sacerdote João Batista Rodrigues, citado acima. 
rede, ter botado e tal. Mas como fizeram com ele não se faz com um ser humano. É milagroso por o motivo daquela humilhação, que fizeram com ele na morte dele, que ele devia ter sido tratado como gente, e não como um animal. ${ }^{16}$

O cortejo excepcional ocorria porque a condição de bandido passou pelo julgamento final, e na verdade, a exposição de ter sido "amarrado e carregado como um porco" parecia a última punição. É necessário dizer que a exibição do corpo do bandido, a exemplo da que ocorreu com João das Pedras já esteve presente em outros momentos na História do Nordeste. Maria Isaura Pereira de Queiroz elucida que a cabeça de Lampião, exposta em Santana de Ipanema, em Alagoas, atraiu curiosos de diversos lugares que queriam ver o famoso e temido cangaceiro morto, dentre os demais que também foram surpreendidos pela volante:17

As cabeças dos onze cangaceiros foram arrumadas nas escadarias da igreja Matriz, na praça do Monumento, e ali ficaram expostas à curiosidade pública. Gente de todo estado de Alagoas correu para vêlas, e, mesmo vendo, não acreditava no que via. Ninguém acreditava que ele viria a morrer de morte matada, e sim que só morreria de morte morrida (Queiroz, 1977, p. 120).

O trajeto de João das Pedras do espaço privado para o público, assim como a profanação do corpo morto, seguia um desenlace comum ao recebido por outros bandoleiros em diferentes épocas e circunstâncias. O julgamento e a execução pública, tão comuns no período colonial brasileiro, são trazidos por Franklin Távora na narrativa da morte do bandoleiro pernambucano Cabeleira, matador que foi executado por enforcamento em praça pública. Para Távora,

No instante, aos olhos da multidão profundamente abalada, a cena transformou-se como por oculto maquinismo. O infeliz mancebo, que, mal acabara de falar tenha sido rudemente impelido do estrado para o vácuo, pendia da corda assassina, tendo sobre os ombros o carrasco que apertava com as mãos cobardes o laço sufocante. Cena bárbara que enche de horror a humanidade, e cobre de vergonha e luto, como tantas outras, a história do período colonial (Távora, s/d, p. 106).

A cena narrada por Távora busca frisar com eloquência o "horror" e a "barbárie" do fim do Cabeleira, mesmo diante dos crimes cometidos por ele. Aqui há uma "multidão" que também assiste e permite mesmo que "abalada" a punição. Em São Benedito, pude perceber que a identificação de seus devotos com João das Pedras parte da concepção do sofrimento por ocasião da morte. Podemos cogitar que o fio que o matou foi o símbolo que o salvou. Oscar Calavia Sáez analisa a morte de Jandira dos Santos que ateou fogo a sua roupa em 23 de agosto de 1934, em Campinas, São Paulo. Tratava-se de uma prostituta que teria decidido

16 Entrevista realizada pela autora a Maria Aparecida de Matos Carvalho, 53 anos, agente de saúde, no dia 07/03/2005, em sua residência, na Rodovia da Confiança Norte, em São Benedito.

17 Assim era denominada a polícia do período no Sertão Nordestino. 
dar cabo da própria vida por ter sido abandonada e desprezada por um amor. Após sua morte, surgiram relatos de que operou milagres, passando a ser considerada santa popular, cultuada por prostitutas e por outros setores da sociedade de Campinas identificados com o abandono que ela sofrera e sensibilizados pela forma como veio a falecer (Sáez, 1996. p. 187).

Como podemos ver, a devoção ao ladrão de São Benedito considerado milagreiro não está isolada. Eliane Tânia Martins de Freitas analisou os cultos prestados a José Leite de Santana, o cangaceiro Jararaca, em Mossoró, e ao bandido João Baracho, em Natal. Jararaca foi sangrado no pescoço e enterrado vivo em Mossoró, morte martirizada e considerada premeditada e covarde por seus devotos. O bandido João Baracho, por sua vez, foi fuzilado pela polícia, em Natal, em 1962. Para os devotos, a vida de crimes destes santos não interferiu na fé coletiva nos poderes de concessão de milagres (Freitas, 2006. P. 20). Nesses casos, a piedade, a comoção e a crença de que o arrependimento dos crimes cometidos e a violência das mortes são os fatores que legitimam a devoção.

Situação similar ao que ocorreu com João das Pedras, em São Benedito, onde as circunstâncias e os desdobramentos de sua morte parecem ter sido fundamentais para o desenvolvimento da narrativa entre seus devotos de que seus roubos eram a prova de sua "caridade para com os pobres". Mesmo quando a compreendidos pela ótica da ilegalidade, as falas dos entrevistados mencionam o arrependimento na hora da morte e o repúdio ao cortejo excepcional. Aspectos fundamentais no processo de transformação de João das Pedras num santo popular aos olhos dos devotos. A sua morte apresenta "uma imagem de morte absurda, rápida, e casual. Uma morte que, de nenhuma maneira, é resultado de um processo natural" (Portelli, 2002, p. 25).

O sofrimento e o martírio são parte do processo de construção dos santos oficiais do catolicismo. O conceito de quem é mártir foi modificado ao longo dos séculos. De acordo com Solange Andrade Ramos, a concepção inicial do mártir e, portanto, da primeira modalidade de santo, foi determinada pela defesa da fé cristã, quando sujeitos comuns entregaram a vida pela sua crença em Jesus Cristo na Antiguidade romana. A santidade dos mártires consistia em perceber que sua morte era um verdadeiro testemunho de fé, assistido pela comunidade que viu "um dia, sua morte exemplar. O martírio era o sacrifício perfeito e implicava em perfeição espiritual alcançada", adquirindo como recompensa a santidade (Andrade, 2008, p. 241). Num segundo momento, a concepção de martírio foi ampliada na religiosidade católica, de modo que "uma morte violenta" derivada "de uma doença grave ou um crime atroz" passou a ser considerada martírio. Solange Andrade Ramos concluiu que "a relação sofrimento/santidade é utilizada há muito tempo para justificar a ideia de purificação, presente no sofrimento" (Andrade, 2008, p. 241)

João das Pedras não pôde receber velas, preces e promessas onde morreu, nem cruz que indicasse que ali fora o local de sua morte-martírio. Afinal, o local era uma residência. Naquele espaço, a sua morte não poderia ser (re)lembrada, segundo assegurou o Padre João Batista:

Depois de uns cinco, seis dias, alguém queria acender alguma vela, 
alguma coisa, não é, no local, mas como era na cozinha, que hoje é um quarto, sugerimos: - É, não seria melhor a senhora acender lá no cemitério, no túmulo dele? Pronto, não tinha nenhuma reação. ${ }^{18}$

Na fala do Padre João Batista é possível notar o direcionamento que fez para que as velas acesas pela alma de João das Pedras fossem levadas diretamente para seu túmulo no cemitério. Se foi por sua influência ou não, o fato é que foi especificamente no túmulo que João das Pedras passou a receber a graça de milagreiro. Não é possível precisar a data do início da devoção, mas a primeira promessa dita pelos entrevistados foi a de uma senhora pobre que pagou pela construção do túmulo de João, mas pediu anonimato, como nos informou o pedreiro, Expedito Jorge:

Pediu que eu nunca dissesse quem era quem tinha mandado. Quem perguntasse, dissesse que não tinha sido ela que mandava fazer. Quando foi um dia, chegou uma senhora lá. Eu tava fazendo o tumulo, e disse: - Fulana, fulano disse que tinha feito o túmulo do João das Pedras. Eu fiquei calado, porque não ia responder. Uma pessoa de fora, do sítio. No caso, tinha sido daqui de dentro da rua, uma família pobre que mandou fazer. Foi uma família pobre. Ela tinha alguma promessa a fazer e então mandou eu fazer esse tumulo lá. Só uma gaveta, eu fiz por vinte cruzeiro naquele tempo. A mulher me conhecia, aí, então, quando ela fez, ela pediu pra eu nunca dizer pra ninguém, e eu nunca disse, eu tô dizendo agora, a pessoa ainda mora aqui em São Benedito. Lá só tinha a cova e o terreno limpo, aí eu fiz o tumulo só de uma gaveta, aí chegaram e botou ele dentro. Só fiz a cruz e fiz uns enfeites para a cruz. Eu nunca falei nem para a mãe dele. ${ }^{19}$

A construção tumular misteriosa é compreendida como pagamento de promessa e passou a ser o espaço da devoção maior ao milagreiro. João das Pedras recebeu um monumento em sua homenagem em agradecimento por um milagre que teria feito. O monumento funerário seria um dos sentidos especializados pela categoria monumento, adotada por Jacques Le Goff. Quando erigido, seus construtores creem na imortalização de quem fora o homenageado pela construção. De acordo com Le Goff, isso é uma verdade que se arrasta desde a Antiguidade romana: "um monumento funerário destinado a perpetuar a recordação de uma pessoa no domínio em que a memória é particularmente valorizada" (Le Goff, 2003, p. 526).

As memórias valorizadas sobre João das Pedras estão associadas à devoção. A acreditar em João das Pedras como concessor é uma escolha particular para alguns devotos, mas, para outros, é uma crença repassada pela família. Assim, o filho ou filha que assiste aos pagamentos de promessas, num futuro próximo também poderão dar seguimento às promessas ao milagreiro, a exemplo do que ocorreu com Otalício Viana:

Todos os dias que a gente, dia de finados a gente toma esta admiração.

18 Entrevista realizada pela autora ao sacerdote João Batista Rodrigues, citado acima.

19 Entrevista realizada pela autora a Expedito Jorge Coutinho, 78 anos, pedreiro aposentado, no dia 03/01/2008, em sua residência na travessa Francisco Cavalcante, em São Benedito. 
Desde pequeno minha mãe me traz aqui, fala sobre a vida dele e eu admiro muito, e como agradecimento eu venho acender uma velhinha, rezar aqui um pai-nosso e uma ave-maria pra agradecer a ele. ${ }^{20}$

O túmulo do João das Pedras é o que mais recebe velas e o único a ter ex-votos em todo o Cemitério de São Benedito. A devoção ocorre em demasia no dia 02 de novembro. Os ex-votos ali expostos apresentam a diferença entre o morto comum e o milagreiro. Os devotos denominam os ex-votos de madeira como milagres:

Dia de finado, menina, era tanto milagre em cima da cova do túmulo desse rapaz. O que o povo fazia, tinha meu irmão que ele ia pra lá de plantão. Ora, aqui não é para botarem vela, para não queimar os milagres. O povo fazia era os montes e queimavam. E hoje em dia está do mesmo jeito. Ninguém, eu não vou mais pedir graça ao finado João, porque [...] não. Hoje em dia, até o padre faz. ${ }^{21}$

No presente, são os devotos que, segundo a entrevistada, solicitam que os sujeitos não coloquem as suas velas próximas aos ex-votos, para que sejam preservados. A quantidade de velas, ex-votos e visitantes no túmulo do João das Pedras no Cemitério de São Benedito indicam a presença de um milagreiro. Francisca das Chagas assegura que: "Lá no túmulo dele tem tanto milagre... Quando é dia de finado, acende tanta vela, quero que você veja. Onde se acende mais vela é lá, acende mais lá do que na igreja". ${ }^{22}$ As visitações ocorrem em diversos dias e meses do ano, não se restringindo ao dia de finados ou à visitação familiar, embora no dia 2 de novembro os devotos se avolumam. As promessas são votos de saúde para os devotos. O Cemitério está sempre de portões abertos durante o dia, o que facilita a vinda destes em qualquer dia e horário:

Me apresentou uma dor muito grande aqui em meu braço. Aí, eu vim para o hospital. Cheguei, justamente, era no dia de finado. Não tinha médico. Aí, eu fui até a farmácia, lá o farmacêutico passou um medicamento pra mim, aí eu tomei, aí eu tive na casa de uma amiga, ela deu uma massagem. Aí eu me deitei lá um pouco, aí quando eu melhorei, aí vim para o cemitério. Vim até o João das Pedras, me peguei com ele, fiz a promessa, que era pra mim fazer: a promessa era pra mim fazer o bilhete pra queimar na cova dele, que era pra fumaça subir até chegar o Nosso Pai. Então eu alcancei as graças e hoje tô aqui pagando. Foi no dia de finado do ano passado e já agora nesse ano vim pagar. Tô boazinha, eu não senti mais nada. ${ }^{23}$

20 Entrevista realizada pela autora a Otalício Viana Soares, 22 anos, auxiliar de escritório do Cartório Amaral do 2 은 Ofício, no dia 02/02/2005, no cemitério de São Benedito.

21 Entrevista realizada pela autora a Maria Ferreira Gomes, citada acima.

22 Entrevista realizada pela autora a Francisca das Chagas Assis, 60 anos, funcionária pública, no dia 19/03/2004, em sua residência na rua Monsenhor Custódio, em São Benedito.

23 Entrevista realizada pela autora a Gonçala Araújo de Paiva, 57 anos, funcionária do Conselho Fiscal do Sindicato dos Trabalhadores Rurais e da Diretoria do Comitê do Programa Fome Zero, no dia 02/02/2005, no cemitério de São Benedito, quando sua visita ao túmulo de João das Pedras 
A aglomeração começa logo que os portões se abrem pelas seis da manhã do dia 2 de novembro. Este passa a ser o dia de pedir e, principalmente, agradecer ao milagreiro. Tomaz Bezerra é um dos devotos que zelam o túmulo do João das Pedras (Figura 1). A cada ano desde que acompanho a devoção (2002), o mesmo senhor realiza modificações no espaço, sempre buscando melhorar a sua estrutura, colocando canteiros de rosas, azulejos e até o nome de batismo do Milagreiro, João Ferreira Gomes. As cores do Túmulo também passaram por estas transformações, há um espaço especifico para o depósito de velas:

Ele é milagroso, ele roubava pra dar o pessoal. [...] Mataram o pobre do rapaz de eletricidade [...]. Eu vou mandar fazer um canteiro aqui, se Deus quiser, porque o Pai do Céu mandou tomar de conta da alma dele. Porque o pessoal encontra as graças com ele, mas não sabe zelar o que é dele, né. Mandei pintar, porque tá uma sujeira danada, a caixa eu mesmo botei milagre dentro, porque ficou melhor, né. Deus abençoe todo mundo, né. ${ }^{24}$

Figura 1. Túmulo do João das Pedras

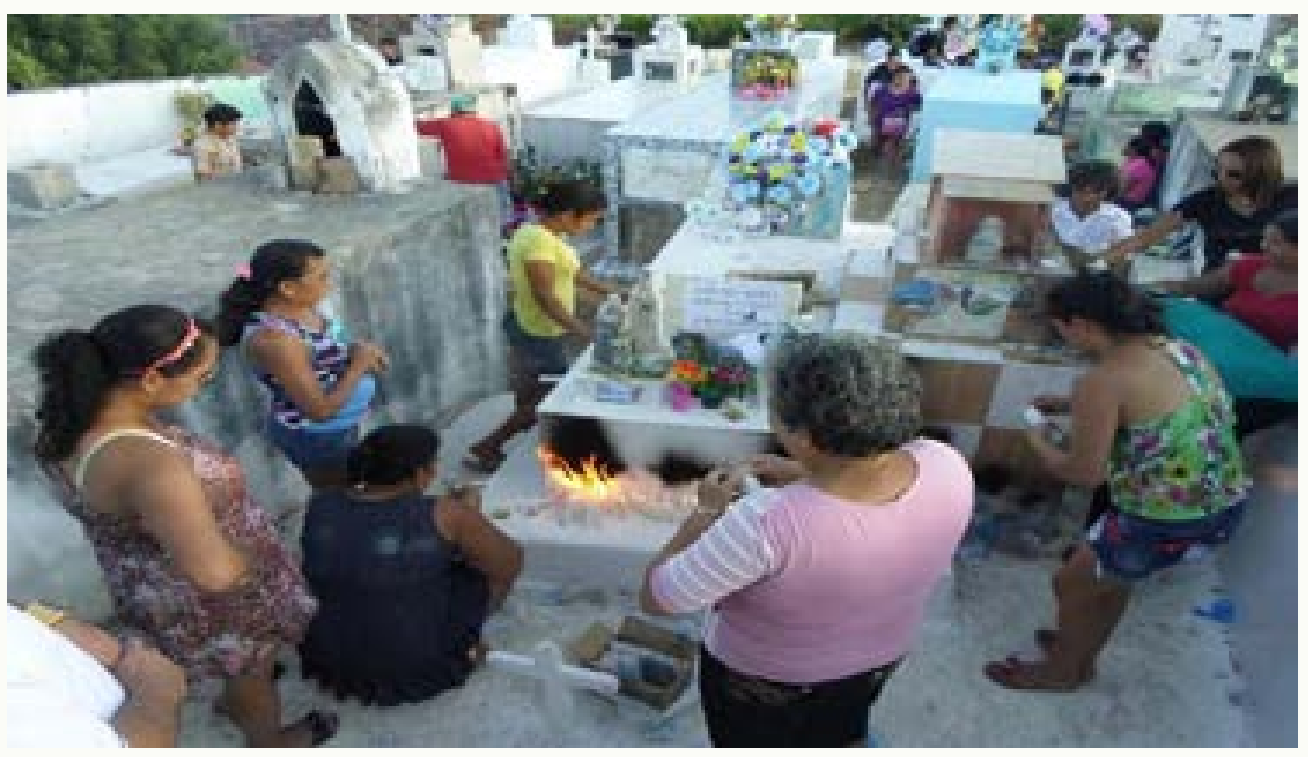

Fonte: Fotografia da autora (2014)

O Cemitério de São Benedito é o lugar mencionado pelos devotos como o espaço do milagreiro. A devoção no Túmulo pode ser compreendida como umas das características do culto aos santos populares. Em seu já mencionado estudo sobre a devoção ao Menino Antoninho, em São Paulo, Marília Schneider, afirma que as formas mais comuns de pagamento das promessas ao menino que morreu tuberculoso, em 21 de dezembro de 1918, são "mandar publicar ou comunicar a graça, acender velas no túmulo do santinho ou visitar seu túmulo, mandar rezar missa para o mesmo" (Schneider, 2001, p. 87).

O Cemitério é o espaço de reunião dos devotos, lugar onde os passos da fé no milagreiro são compartilhados, onde as histórias se cruzam nas descrições das dificuldades

24 Entrevista realizada pela autora a Tomaz Bezerra Silva, 66 anos, pintor de casas, no dia 02/02/2005, no cemitério de São Benedito, quando sua visita ao túmulo de João das Pedras. 
e principalmente nas do alcance da graça. Não existe uma organização dos devotos do João das Pedras, no sentido de se reunirem para ir ao túmulo. Algo também comum em outros casos de devoções a milagreiros. Na observação do culto ao cangaceiro Jararaca, Kesia Alves afirma ter compreendido que os fiéis e curiosos "se aglomeram para tentar se aproximar do túmulo do cangaceiro". Uma de suas observações é que "a visitação ao túmulo é feita de maneira aleatória, desorganizada. Não há um grupo de fiéis de Jararaca. É um rito particular pertencente ao espaço do sagrado". A visitação em demasia ao cangaceiro ocorre em maior concorrência também no dia de finados (Alves, 2006, p. 78).

A morte e o cortejo foram os rituais iniciatórios da devoção ao João das Pedras. A reunião dos devotos na sepultura discute também as promessas, o que alcançaram de graças. Depois, o momento é particular. Mesmo em meio às velas, à fumaça e aos demais sujeitos que ali estão presentes, o devoto balbucia de olhos fechados o seu agradecimento ou um novo pedido. Esta cena se repetiu durante os anos que estava como pesquisadora no túmulo do João das Pedras. Mesmo quando o túmulo está sem os devotos, estes se apresentam pelas marcas da devoção expressa na quantidade de velas ali depositadas. Exemplo disso é a imagem das onze horas da manhã do dia 02 de novembro de 2019 (Figura 2).

Figura 2. Túmulo do João das Pedras

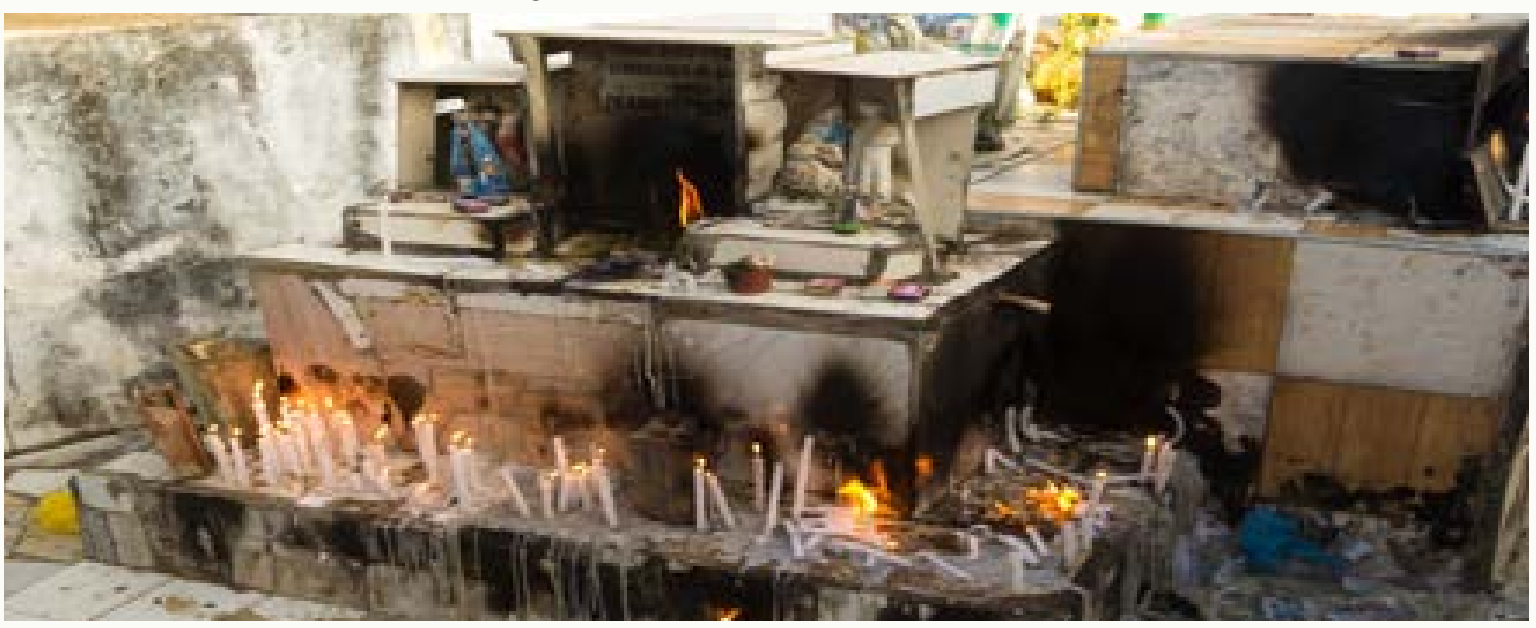

Fonte: Fotografia da autora (2019)

\section{Dr. Olavo Cavalcante Cardoso: a morte e "santidade" do médico caridoso}

No Cemitério Municipal de Crateús, o Dr. Olavo Cavalcante Cardoso recebe a visitação dos seus devotos. Foi médico e prefeito em Crateús, tendo morrido assassinado na sua Fazenda Xavier, em 2 de setembro de 1969. A morte foi resultado de uma luta corporal entre o médico e agricultores durante uma discussão sobre os limites da referida fazenda. Quem adentra no espaço cemiterial avista os volumosos ex-votos deixados pelos pagamentos de promessas. Em sua maioria ex-votos de madeira (Figura 3). 
Figura 3. Imagem da lateral esquerda do túmulo do Dr. Olavo Cavalcante Cardoso

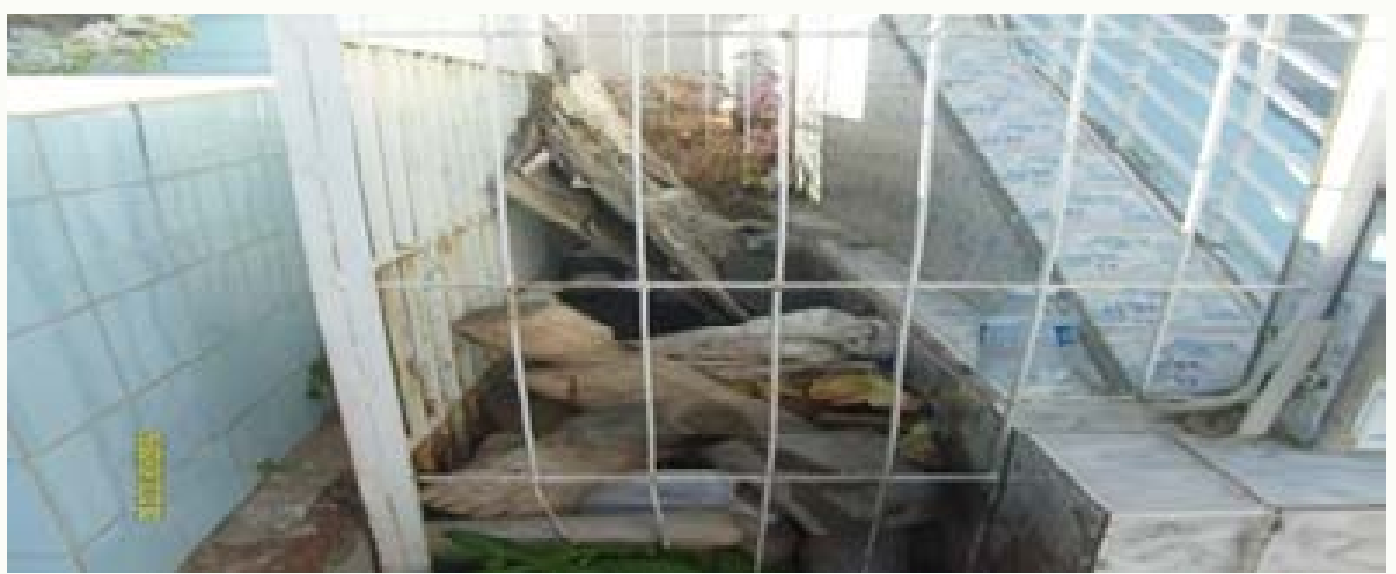

Fonte: Fotografia da autora (15 de fevereiro de 2010)

Na cidade de Crateús, o Dr. Olavo Cavalcante Cardoso era conhecido por ser "humanitário e caridoso", por atender aos pobres que the procuravam, principalmente, as mulheres que eram as mais socorridas:

O Dr. Olavo sempre foi tido aqui, em Crateús, uma pessoa muito boa. Era um médico humanitário, atendia as pessoas no consultório, no meio da rua, na casa dele, em todos os lugares. As pessoas que não tinham condição de comprar o remédio ele, além de receitar, ainda dava o medicamento. Era uma pessoa muito querida, iluminada por Deus. Aqui existia só a Policlínica. Ele saía, de madrugada, de casa, pra atender urgência, pra qualquer que fosse a pessoa. ${ }^{25}$

Era um dos proprietários da Policlínica (um hospital particular, em Crateús). Seus atendimentos eram compreendidos como caridade por muitos, como assim nos relata também Maria do Socorro Monte Barbosa, segundo a qual o médico ia consultar sua irmã e sobrinhos na casa dela ou na de qualquer um que o chamasse, "Ele era um médico caridoso, bom mesmo!" (Maia, 2019, p. 41).

A cidade de Crateús contava com dois únicos hospitais na década de 1960. O Hospital Regional do 40 Batalhão de Engenharia e Construção, que realizava atendimentos gratuitos à população em geral, e a Policlínica de Crateús, instituição privada particular, que teve como um dos fundadores e proprietários o próprio Dr. Olavo Cavalcante Cardoso. Os casos mais graves eram conduzidos para a Santa Casa de Misericórdia, em Sobral ou Fortaleza. Somente em primeiro de novembro de 1979 seria fundado o Hospital São Lucas, pelos médicos Dr. José Fernandes da Silva e Dr. Francisco Sales de Macedo, que, de início, funcionava como hospital particular. Na década de 1980 foi denominado Hospital Geral de Crateús e passou a realizar atendimentos de ordem pública.

A carência de hospitais públicos e as dificuldades de acesso aos particulares por parte

25 Entrevista realizada pela autora a Márcio Campina, 38 anos, radialista, em 7/9/2009, em sua residência na Rua Coronel Jiló, bairro São Vicente, em Crateús, Ceará. 
da população carente da localidade contribuiu para que os atendimentos feitos pelo doutor Olavo Cavalcante Cardoso, mesmo aos que não pudessem pagar, o transformassem num um médico humanitário. Cleomar Ferreira Batista relata a percepção que tinha, quando criança, da atitude do médico que, além de atender aos necessitados, também doava medicamentos:

Eu adoeci e não tinha remédio que curasse. Já era tarde da noite, quando eu acordei sem poder respirar, nem nada. Meu irmão mais velho, com a minha mãe e meu pai me levaram. A mamãe quando chegou lá na farmácia os farmacêuticos não entendia o problema. Aí disse: - o Dr. Olavo tá bem aqui com uns amigos dele. Eu chamo já ele para olhar. Ele tava na roda de amigo, bebendo, quando o rapaz foi chamar. Ele só fez falar que tinha uma menina morre num morre, sem respirar mais. Ele deixou tudo e foi me atender. Quando chegou, mandou aplicar logo uma injeção. Depois ainda encheu minhas mãos de balinha. Meu pai perguntou quanto era; ele disse que deixasse com ele a injeção que tinha pegado na farmácia e os remédios que tinha me dado para mim tomar em casa. Ele não queria nada. ${ }^{26}$

As crianças e as mulheres grávidas são as mais descritas nas narrativas sobre as consultas do médico. Esta informação é relevante ao se constatar que são estes pacientes que compõe a grande maioria de seus devotos. Os atendimentos do Dr. Olavo Cavalcante Cardoso não se restringiam à cidade, socorrendo muitas mulheres com complicações no parto, segundo relatos, como os de Maria de Fátima do Carmo Lopes. ${ }^{27} \mathrm{~A}$ senhora explica que sua mãe foi socorrida pelo médico quando teve complicações no parto: "Minha mãe viveu muitos anos por causa dele. Porque [...] ia ganhar neném, e o neném tava atravessado. A gente morava na fazenda. Ele era médico muito bom, dificilmente uma pessoa morria nas mãos dele. Ele salvou a vida de muitas e muitas mulheres, de muitas, principalmente, de parto". ${ }^{28}$ As narrativas sobre o Dr. Olavo Cavalcante Cardoso o equiparam a outros médicos igualmente conhecidos no Brasil como dedicado aos pobres. Trajetórias de vida unidas pela formação e dedicação à medicina e, principalmente, pelo destino que tiveram após a morte. Citaremos três exemplos em particular.

O cearense Dr. Adolfo Bezerra de Menezes Cavalcanti - nascido, em 1831, no Riacho do Sangue, então Província do Ceará, e formado em medicina no Rio de Janeiro - ficou conhecido como o médico dos pobres porque sempre trabalhou junto às classes sociais menos favorecidas, especializando-se no tratamento de pessoas com problemas mentais. Após a morte, foi considerado um espírito de luz. ${ }^{29}$ O Dr. Camilo Salgado, nascido em 22 de maio de 1874, cursou até o quarto ano de medicina em Salvador e depois se transferiu para o Rio de Janeiro, onde se diplomou em 1911. Trabalhou em Belém do Pará, onde era um exímio

26 Entrevista realizada pela autora a Cleomar Ferreira Batista, 49 anos, doméstica, no dia 05/04/2013, em sua residência no bairro Cachoeira, em São Benedito. Falecida em 15 de novembro de 2019.

27 Entrevista realizada pela autora a Maria de Fátima do Carmo Lopes, 53 anos, residente em Crateús, professora aposentada, casada, no dia 19/07/2008, em Fortaleza, quando de sua visita à casa da filha, Ana Keyla Lopes, residente na Avenida Jovita Feitosa.

28 Idem.

29 Segundo Antonio Mourão, o Dr. Adolfo Bezerra de Menezes Cavalcanti "chegou a organizar uma classificação dos distúrbios mentais e a estruturar modelos de intervenção terapêutica, principalmente as relacionadas aos mecanismos de desobsessões. [...] seria também conhecido como um grande propagador da doutrina espírita" (CAVALCANTE e GREENFIELD, 2003, p. 15-16). 
cirurgião. De acordo com Aristoteles Guillio de Miranda, destacou-se pelo pioneirismo e o grau de dificuldade de seus atos médicos, os quais lhe deram fama e notoriedade entre seus pares e parte da comunidade beneficiada por seu trabalho, principalmente os mais pobres, a quem atendia sem visar recompensa financeira. Um dos fatos relatados sobre seu desprendimento é a falência de uma farmácia da qual seria dono, tantas foram as doações de medicamentos a quem não tinha dinheiro. Em 1938 morreu acometido por um infarto, aos 55 anos (Miranda, 2006). Desde então, passou a ser cultuado como santo popular em Belém. ${ }^{30}$ Nascido em Maranguape em 1911, Dr. Argeu Gurgel Braga Herbster, também formado no Rio de Janeiro, destacou-se a partir de 1941 em sua cidade natal pelo seu devotamento aos pobres, aos loucos e às mulheres grávidas. Atendia, sem distinção, todos os pacientes e doava medicamentos aos despossuídos. ${ }^{31}$ Segundo Antonio Mourão Cavalcante, o médico nunca concorreu a nenhum cargo político, apesar de sua família ter dominado o cenário político de Maranguape nas décadas de 1960 e 1970. Faleceu aos 50 anos e tornou-se objeto de devoção em sua cidade. ${ }^{32}$

Os predicados de humanitário e caridoso do Dr. Olavo Cavalcante Cardoso lhe renderam votos na eleição municipal para prefeito de Crateús no ano de 1962. Enquanto prefeito, não contou com a mesma sorte, sendo visto como mau administrador e falsificador de leis, e por esta razão foi retirado do cargo em 1966 (Maia, 2019). Entretanto, esta questão administrativa e o seu afastamento advindo pela Câmara de Vereadores pouco interferiram na sua aceitação pelo povo, pois continuava sendo visto como médico caridoso e humanitário.

A aparente contradição pode ser compreendida conforme a argumentação de Marília Schneider, para quem a vida do santo tende a ser recortada com o intuito de selecionar apenas as atitudes que já apresentariam ou anunciariam a sua santidade, eliminando tensões ou quaisquer contradições que tenham marcado o dia-a-dia" do hagiografado (Schneider, 2001, p. 365). Segundo Michel de Certeau, a hagiografia é "a rigor um discurso de virtudes", que veste o santo pelo extraordinário e pelo maravilhoso. O que podemos caracterizar na hagiografia escrita e falada do Dr. Olavo Cavalcante Cardoso como extraordinário seriam os atendimentos aos pobres e o maravilhoso expresso nos atendimentos que teria realizado após a morte, as curas, os milagres (Certeau, 2006, p. 273). Esse recorte de memória pode ser compreendido conforme as afirmações de Ulpiano Bezerra de Menezes, para quem a memória é um mecanismo de seleção, de descarte, de eliminação. Esquecer, sem dúvida, é condição de vida humana. Entendemos que o propósito da eliminação e do esquecimento percebido nos relatos da trajetória do Dr. Olavo Cavalcante Cardoso pauta-se na intenção de legitimar e reforçar a imagem de santidade do médico. Deste modo, as narrações dos fatos priorizaram

30 Outras características percebidas nas trajetórias dos doutores Olavo Cavalcante Cardoso e Camilo Salgado é que, na construção da santidade deste último, é a constante menção a a sua "bondade" ", atuando como "uma espécie de 'salvador' das camadas pobres da cidade por atendê-las seja de dia, seja de noite" são sempre mencionadas (Costa, 2010, p. 53).

31 Segundo Cavalcante e Greenfield, "Ele atendia também aqueles que não podiam pagar, dedicando tanto tempo quanto com aqueles que remuneravam o ato. Ele atrasava as consultas muitas vezes na semana para atender aqueles que não tinham condições financeiras" (Cavalcante e Greenfield, 2003. p. 28).

32 Para Antonio Mourão Cavalcante e Sidney M. Greenfield, o reconhecimento do Dr. Argeu como santo popular era quase inevitável, uma vez que foi "um médico tão conhecido e de tão renomada competência, associado a uma constante disponibilidade de atendimento a todos, não tivesse sua fama crescente no conceito do povo. Ele passou a ser procurado por todos aqueles que sofriam. Ele é a última chance de cura para os desesperados" (Cavalcante e Greenfield, 2003, p. 36-41). 
as consultas, o sofrimento do assassinato e os milagres (Menezes, 2007, p. 23). Vejamos mais sobre sua morte.

Dr. Olavo Cavalcante Cardoso residia em Crateús e possuía também a Fazenda Xavier, localizada fora da cidade, num lugar onde passava os fins de semana com sua família. O vaqueiro Zuza residia com a sua família na fazenda para cuidar dos animais e da propriedade. O espaço possuía limites com a propriedade dos agricultores que, conforme as narrativas jornalísticas e também dos entrevistados, tentavam adentrar no território que era de posse do Dr. Olavo Cavalcante Cardoso. A reportagem do jornal Tribuna do Ceará nos apresenta os fatos daquele dia:

\section{Com Cinco Facadas Assassinado Médico e Ex-Prefeito}

Segundo se informa, os agricultores José Cândido e Felício Crateús derrubaram na propriedade do Sr. Olavo 60 braças de cêrca, alegando que a mesma avançava em sua propriedade. Prolongaram a polêmica que terminou em luta corporal. No entanto, sabe-se que o Dr. Olavo foi atingido por 5 profundas facadas, tendo morte imediata. Colhemos ainda através do Serviço Estadual de Radiocomunicação que a briga teve início quando Dr. Olavo foi informado pelo seu vaqueiro da derruba da cêrca, dirigindo-se imediatamente para sua Fazenda de nome Xavier. Lá chegando, encontrou - se com os seus dois vizinhos de terra. Iniciaram a discussão e o Dr. Olavo vendo que o caso era de vida ou morte sacou de seu revólver e disparou três tiros contra José Cândido, atingindo-lhe de raspão. Nesta oportunidade, Felício Crateús aplicou-lhe 5 profundas facadas, postando-o ao chão sem vida. ${ }^{33}$

A disputa pelas "60 braças de cêrca" da Fazenda Xavier não era recente. $O$ antigo proprietário da fazenda, Cícero Soares, também havia sido assassinado a facadas em 4 de setembro de 1969, no conflito envolvendo os vivinhos Manuel Lino, José Rodrigues e Felício Crateús, que se diziam donos há mais de trinta anos de uma faixa de terras que ainda não havia sido cercada e ocupada por Cícero Soares. ${ }^{34} \mathrm{~A}$ referência a outro conflito por terras envolvendo aquela propriedade pode nos mostrar a diferença entre o impacto da morte do primeiro proprietário e o doutor Olavo, pois apenas esse ganhou atributos de santidade após a morte. Não foi informada a distância temporal entre os dois homicídios, entretanto a intensa cobertura sobre a origem e o desfecho do segundo levou-nos a refletir sobre a fabricação da santidade do médico, tendo em vista o tratamento distinto dispensado ao seu caso, apesar de ambos terem a questão da terra como o mesmo ponto de partida.

Os jornais Gazeta de Notícias e Tribuna do Ceará, em circulação à época em boa parte das cidades cearenses, proporcionaram larga repercussão ao segundo caso, elevando-o à categoria de caso de estado, enquanto o assassinato de Cícero Soares obteve somente repercussão local, tendo sido apresentado como mais um motivado pela querela sobre a posse

33 "Com cinco facadas assassinado médico e ex-prefeito de Crateús". Tribuna do Ceará. Fortaleza, ano XII, n. 4.911, de 3 de setembro de 1969, p.12.

34 "Continua Foragido um dos Matadores do Ex-Prefeito de Crateús". Autor desconhecido. Gazeta de Notícias, Fortaleza, ano XLIII, n. 12.186, quinta-feira, 4 de setembro de 1969, p. 6. 
de terras, comum no sertão cearense. De fato, o que diferenciava os dois crimes era o status do proprietário. Cícero Soares foi apenas um dos proprietários daquela fazenda e Olavo Cavalcante Cardoso, por sua vez, era prefeito e médico da cidade, sendo, portanto, uma representação da elite local. Privilegiou-se um acontecimento a outro na compreensão de que a morte de um, era aceitável, mas a do médico inadmissível (Maia, 2019).

Nas entrelinhas dos discursos jornalísticos e mesmo nas vozes dos crateuenses a diferenciação se apresentava na origem "nobre" (entendendo-se por nobreza, neste exemplo, a posição de destaque que ele ocupava na cidade) do médico e ex-prefeito. A condição de vítima foi atribuída somente ao Dr. Olavo Cavalcante Cardoso, sendo destacado como o homem público assassinado por homens comuns: os agricultores. ${ }^{35}$

Conforme Michel de Certeau, na hagiografia e estrutura do discurso sobre um santo "a individualidade conta menos que o personagem. Os mesmos traços ou os mesmos episódios passam de um nome próprio a outro: as combinações destes elementos flutuantes, como palavras ou joias disponíveis, compõem tal ou qual figura e the atribuem um sentido. Mais do que o nome próprio, importa o modelo que resulta desta 'tergiversação'; mais do que a unidade biográfica, o recorte de uma função e do tipo que a representa" (Certeau, 2006, p. 273). No nosso caso, portanto, a individualidade do médico foi deixada de lado para que a imagem do santo martirizado fosse construída. Na exposição da morte do Dr. Olavo Cavalcante Cardoso foi propagada a sua origem nobre, característica básica na descrição hagiográfica do santo. Segundo Michel de Certeau, a utilização da origem nobre (conhecida ou oculta) não é senão um sintoma da lei que organiza a vida do santo. ${ }^{36}$

Sua morte foi vista como "trágica". ${ }^{37}$ A ênfase dada à quantidade de perfurações procurava assinalar a violência da qual fora alvo. Arrisco a inferir das entrelinhas deste discurso que a intenção dos agricultores naquela ocasião era matá-lo, fosse por legítima defesa do corpo e da terra ou por ira e ódio pelas desavenças em decorrência da disputa pelas terras. Tal reflexão se faz possível com base na argumentação de Natalie Zemon Davis sobre a "raiva e a legítima defesa", segundo a qual "por mais que seja a mão que cometa o homicídio, é o coração que o concebe por ira e ódio" (Davis, 2001, p. 63).

Após o confronto, o Dr. Olavo Cavalcante Cardoso "foi colocado no carro e, ainda vivo, transportado para Crateús. Embora o jornal Tribuna do Ceará publicasse que o médico já havia caído morto no local do confronto, ou seja, na Fazenda Xavier, é relatado pelos entrevistados que ele morreu na localidade de Grota, próximo ao açude municipal, distante três quilômetros da cidade" e em consequência não chegou a ser atendido no hospital. A descrição da morte do Dr. Olavo Cavalcante Cardoso aflora a concepção de mártir cristão naquilo que ele tem de vítima imolada: a desigualdade da luta que conferiu a dignidade ao morto (Milliet, 2001, p.

35 Conforme Michel de Certeau, na estrutura do discurso sobre um santo, assim como também na sua hagiografia, "a individualidade conta menos que o personagem. Os mesmos traços ou os mesmos episódios passam de um nome próprio a outro: as combinações destes elementos flutuantes, como palavras ou joias disponíveis, compõem tal ou qual figura e lhe atribuem um sentido. Mais do que o nome próprio, importa o modelo que resulta desta "tergiversação"; mais do que a unidade biográfica, o recorte de uma função e do tipo que a representa" (CERTEAU, 2006, p. 273).

36 Idem.

37 "Continua Foragido um dos Matadores...", op.cit, p. 6. 
143-144). O Dr. Olavo Cavalcante Cardoso morreu sem receber socorro. Antes de morrer teria proferido em sua última frase: "salvei tantas vidas e ninguém vai salvar a minha". A cidade se postou em luto pela morte de seu filho mais ilustre. Maria do Socorro Monte Barbosa relatou, em entrevista, ser a proprietária do lugar onde o médico passou seus últimos instantes:

Trouxeram ele, o motorista butaram lá no carro, em cima, porque ele ainda não tava morto, até falou no caminho. Quando chegou lá no terreiro da minha casa, aí pararam o carro e ele acabou de morrer. Ficou bastante sangue derramado no chão. Eu não vi, que eu não morava lá naquele tempo. O pessoal disse que ele ainda disse assim: - tantas vidas que tinha salvado e agora ia morrer sem ajuda. Morreu novo. ${ }^{38}$

Márcio Campina também repetiu as palavras finais do médico: "vinha no carro, perdendo sangue, já debilitado, devido ter perdido muito sangue aí ele disse lá pra quem vinha com ele: Meu Deus, eu salvei tantas vidas e hoje ninguém vai conseguir salvar a minha. E morreu". ${ }^{39} \mathrm{~A}$ frase sensibilizou os ouvintes, contribuindo para que ficassem mais compadecidos do falecimento do Dr. Olavo Cavalcante Cardoso. As palavras atribuídas a ele suplicavam por piedade e denunciavam a agonia daquele agonizante que evitara a morte de muitos. Era a fabricação da ideia de abandono e da morte sem socorro. Analogia que indiretamente associava-o a Jesus Cristo, quando questionou seu destino ao seu pai na cruz afirmando, segundo o Evangelho de Mateus 27:46: "Deus meu, Deus meu, por que me desamparaste?". ${ }^{40}$ A divulgação do que teriam sido suas últimas palavras teve o poder de conferir mais dramaticidade à morte do médico. O sentido atribuído à frase do Dr. Olavo Cavalcante Cardoso era que o médico merecia ser salvo. Se a salvação do corpo e da vida foi impossibilitada pelos ferimentos das facadas, ela viera através de sua santificação popular. A própria frase foi utilizada como comprovação do rito de passagem do homem para santo. Ouvimos, informalmente em Crateús, que "ele não podia ter mais força para dizer aquilo, tava muito ferido; se ele falou, foi porque já era santo, ele já tinha se santificado". ${ }^{41}$ A morte trágica suplicava por piedade: "Todo mundo ficou com muita dó, porque foi muita crueldade, Ave Maria!". ${ }^{42}$ Quase todos os assassinos conseguiram fugir, salvo o único que ficou para trás, por ter sido alvejado pela pistola do médico. José Rodrigues foi hospitalizado e posteriormente preso. A fuga de parte dos assassinos é sinônimo de impunidade. Diferentemente do João das Pedras, o Dr. Olavo Cavalcante Cardoso recebeu dois espaços de devoção em Crateús: no lugar onde ocorreu a sua morte e no seu túmulo no Cemitério São Miguel. Desde o seu sepultamento, o túmulo do Dr. Olavo Cavalcante Cardoso foi consideravelmente visitado pelos familiares, amigos, admiradores e curiosos, que já acendiam velas dedicadas à sua alma, compadecidos pelo sofrimento de sua morte. Após a divulgação do primeiro milagre, o número de visitantes se tornaria bem mais considerável, movidos pela intenção de pedir graças.

38 Entrevista realizada pela autora a Maria do Socorro Monte Barbosa, 72 anos, casada, doméstica aposentada, no dia 14 de abril de 2009, em sua residência na Rua Firmino Rosa, Centro, Crateús, Ceará.

39 Entrevista realizada pela autora a Márcio Campina, radialista, citada acima.

40 A Bíblia Sagrada. Tradução Ecumênica. São Paulo: Loyola, Brasil, 1996.

41 Entrevista realizada pela autora a Cleomar Ferreira Batista, citada acima.

42 Idem. 
O túmulo do Dr. Olavo Cavalcante Cardoso está localizado na primeira ala esquerda do Cemitério São Miguel e se faz notar logo na entrada do portão principal; o que facilita o acesso dos visitantes. A construção mede aproximadamente 4,55 metros de largura, por 5,95 metros de comprimento e 6 metros de altura. É revestido por um azulejo de cor branca decorada com flores em azul e branco. O piso é de cerâmica de cor cinza. Antes dos degraus e embaixo destes, há um espaço dedicado às velas. Após os degraus, avista-se a entrada do interior do túmulo perpassada pela grade do portão que separa o exterior do interior, fechado a cadeado. O zelador do cemitério detém a posse da chave, sendo ele quem permite ou não a entrada do visitante no recinto (Maia, 2019, p. 90).

Figura 4. Túmulo do Dr. Olavo Cavalcante Cardoso no CemitérioSão Miguel em Crateús

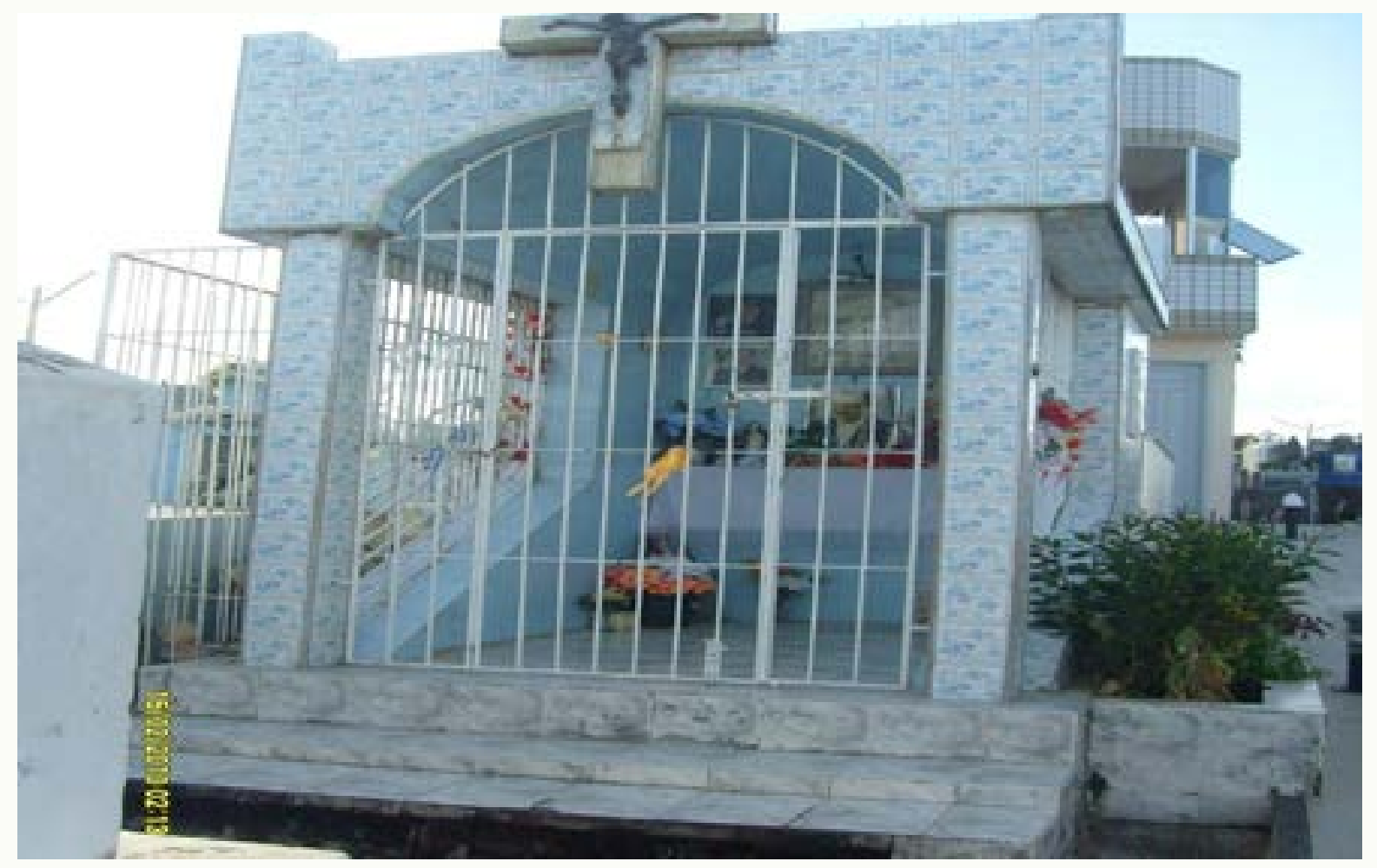

Fonte: Fotografia da autora (15/02/2010)

Os primeiros passos da propagação da santidade do Dr. Olavo Cavalcante Cardoso são vislumbrados a partir da distribuição de uma fotografia. O médico teria aparecido em sonho e solicitado que fizessem seu retrato e o distribuíssem para mães e mulheres. As devotas teriam, assim, um símbolo para realizarem suas preces e promessas. Em Crateús, o Dr. Olavo Cavalcante Cardoso foi reafirmado como o santo das mulheres após uma aparição onírica:

Seis meses que ele tinha morrido. O homem, o Clóvis Ximenes, sonhou com ele pedindo para ele fazer muitos retratos dele não fizesse só um, fizesse muitos e desse a todas as mães, podia ser militris (termo utilizado para denominar as prostitutas - grifo nosso) ou casada. O homem foi e distribuiu. O povo ia buscar lá na loja dele, de cimento, próximo da linha 
do trem, e não deu para quem quis. ${ }^{43}$

O pedido feito em sonho foi respeitado sem nenhuma contestação. Afinal, o respeito à concepção acerca do regresso dos mortos no sertão cearense é mais comum do que se pode quantificar ou descrever. Os limites da fronteira invisível que separa o além do aquém é frequentemente transposta. Por este motivo, a distribuição da fotografia do Dr. Olavo Cavalcante Cardoso, em Crateús, passava a ser um objeto de devoção, um meio de persuasão, de transmitir informações, fosse sobre a vida e morte do médico ou da história do primeiro milagre estritamente relacionado à própria condição da circulação da fotografia na cidade. Acerca disto, Vovelle articulou que "a imagem fala mesmo quando se cala" (Vovelle, 2010, p. 15).

Acredito que os familiares do Dr. Olavo Cavalcante Cardoso participaram da construção da sua imagem de milagreiro, incentivando a devoção. Questão observada tanto na distribuição das fotografias para a realização de promessas, quanto na construção do outro espaço de memória sobre o médico. Este último tratou-se de um cruzeiro construído no local de sua morte para relembrar o seu assassinato e que passou a receber também os pagamentos de promessas (Figura 5).

Figura 5. Cruzeiro em Homenagem ao Dr. Olavo Cavalcante Cardoso

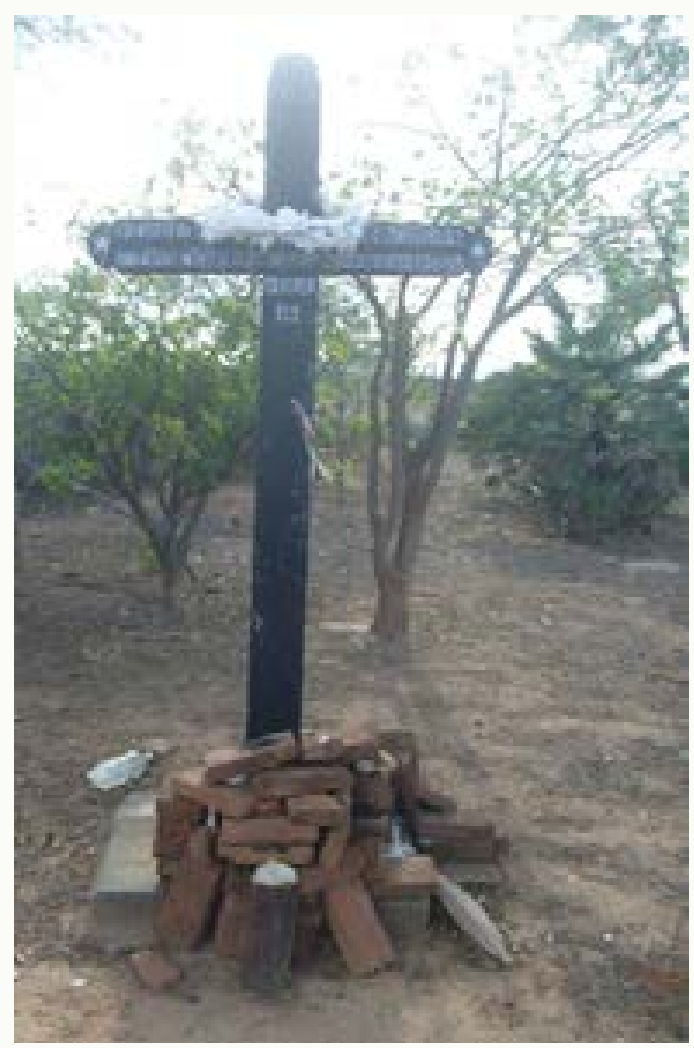

Fonte: Fotografia da autora (15/02/2010)

43 Entrevista realizada pela autora a Raimunda Ferreira Maia, 50 anos, casada, dona de casa, no dia 03/07/2007, em sua residência no bairro do Corrente. 
Segundo Oscar Calavia Sáez, levantar uma cruz é o mesmo que fundar religiosamente um lugar, pois preenche funções rituais especificas (Saèz, 1996, p. 89). Nas diversas regiões dos interiores cearenses, é comum avistar e encontrar uma cruz ou várias cruzes de tamanho e cores diversas à beira da estrada, demarcando o lugar da morte de um sujeito, geralmente vítimas de acidentes de trânsito:

Em outras palavras, as cruzes das estradas são consideradas, de modo semelhante às sepulturas dos cemitérios, como heranças de mudanças histórico-sociais iniciadas no século XVI para marcar individualmente a presença ou lembrança de cada morto. Um acidente não será marcado apenas por uma cruz, mas pelo número de mortes decorrentes dele (Oliveira, 2018, p. 15)

Acredita-se que ao marcar o espaço com uma cruz a intenção é direcionar a alma do morto para o sossego eterno. De fato, para os transeuntes e curiosos, estas marcações indicam quem ali pereceu, como combate ao esquecimento. A erigida cruz em homenagem ao Dr. Olavo Cavalcante Cardoso possui duas inscrições (Figura 6), em horizontal. A primeira, exibe ao visitante a seguinte informação: "Foi morto na sua Fazenda Xavier em 2-09 o conceituado e humanitário médico Dr. Olavo Cavalcante Cardoso nascido 15-08-1925. Orai por ele". A segunda mensagem explica o significado: "Este cruzeiro que fora colocado aqui pelo seu tio Florentino de Araújo Cardoso em 2-10-1969. Constitui Imorredoira Lembrança da Passagem do Extinto pelo Mundo". (Maia, 2019, p. 94). Com a construção do cruzeiro, pretendia-se ir além do recebimento das orações do público compadecido pelo triste fim do médico. De fato, demarcava e reclamava a presença do extinto neste mundo.

Figura 6. Inscrições no cruzeiro em Homenagem ao Dr. Olavo Cavalcante Cardoso

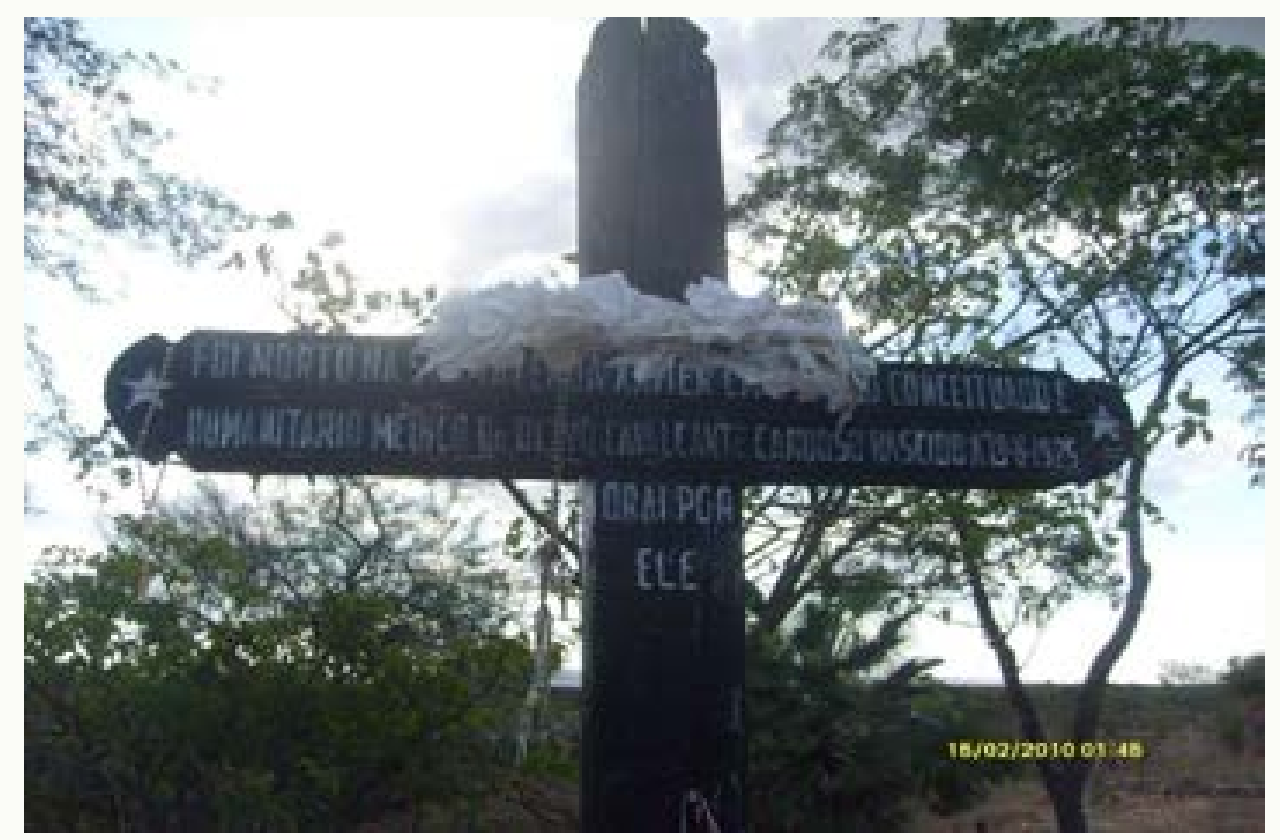

Fonte: Fotografia da autora (15/02/2010) 
A inscrição no cruzeiro se punha como um monumento de lembrança e denúncia da morte do Dr. Olavo Cavalcante Cardoso. Henrique Sérgio de Araújo Batista identificou no Cemitério São João Batista, em Fortaleza, Ceará, o túmulo de José Mendonça Nogueira como um monumento de denúncia, o qual exibia imagens de seu assassinato (Batista, 2003, p. 8890). Para Clarival do Prado Valladares, "a denúncia e o protesto no túmulo da vítima atribuível correspondem a uma forma da vingança, o modo da vingança sublimar-se uma vez na pedra e cal" (Valladares, 1972, p. 605). A denúncia sobre o assassinato do Dr. Olavo Cavalcante Cardoso foi erigida no lugar da morte. A intenção da família era a de deixar rastros sobre os quais o Dr. Olavo Cavalcante Cardoso não fosse esquecido. Compreendemos que neste momento não há indícios da criação do santo diretamente. São os devotos que, posteriormente, aproveitaram o espaço à sua maneira para o pagamento de promessas. O cruzeiro foi construído numa propriedade que, a partir de 1977, seria de Maria do Socorro Monte Barbosa, que assim relatou a respeito do cruzeiro:

\section{O Flor Cardoso que era tio do doutor mandou botar um cruzeiro muito grande lá. Tem o nome dele, data, idade, a data da morte, tem tudo. Já uma época esse cruzeiro ficou feio, largou a tinta toda, e meus filhos pintaram o cruzeiro de preto e as letras de branco. Quando eu fui morar lá em 77, Ave Maria era cheio de gente, dia de finados vai muita gente acender vela e rezar, soltar foguete e tudo e no cemitério também. ${ }^{44}$}

Consideramos que a contribuição da família para a construção e divulgação da imagem do Dr. Olavo Cavalcante Cardoso como santo foi vitoriosa em seu propósito. O médico alcançou o reino das graças pela fé dos devotos e são eles os responsáveis pela manutenção do culto ao santo no presente. Para cada criança ${ }^{45}$ que recebe o nome de Olavo, a memória do santo é regozijada e enaltecida. A cada ex-voto deixado, seja no túmulo ou no cruzeiro, as memórias do crime são discutidas. Afinal, o santo popular nasceu pela e com a morte trágica. Por fim, percebemos que cada devoto do Dr. Olavo Cavalcante Cardoso, que na oralidade compartilha o milagre alcançado, consagra mais uma vez que o médico humanitário de antes é hoje o Milagreiro de Crateús.

Apesar da recorrência de visitas dos devotos no local de morte, a devoção é mais observada no Cemitério São Miguel, em Crateús, no qual as práticas dos pagamentos de promessas ao médico podem ser vislumbradas logo na observação do espaço tumular. Ao contrário do túmulo do João das Pedras, que foi construído por devotos, o do Dr. Olavo Cavalcante Cardoso foi edificado pelos seus familiares. Estes, aos poucos, buscaram direcionar as práticas dos devotos no espaço tumular. Exemplo disso é perceber que o túmulo apresenta um local específico para o depósito de velas e ex-votos. Além disso, a entrada no lugar está restrita à abertura do cadeado que fecha a entrada do recinto. A chave fica com o zelador

\footnotetext{
44 Entrevista realizada pela autora a Maria do Socorro Monte Barbosa, citada acima.

45 A cidade se tornou um lugar comum para a propagação das promessas concedidas pelo Dr. Olavo Cavalcante Cardoso. O nome do médico está por todos os lados de Crateús. Um exemplo é observar uma das formas de pagamento de promessa das devotas na atribuição do nome Olavo ao filho. Isso ocorre como sinônimo de que o parto foi tranquilo: "cada mulher que vai ganhar neném faz essa promessa, e diz que o menino nasce de repente. Em Crateús têm muitas crianças com o nome de Olavo" (Maia, 2019, p. 93).
} 
responsável pelo cemitério, que recebeu ordens da família do Dr. Olavo Cavalcante Cardoso para mantê-lo fechado. Essa tentativa física de controlar o acesso dos devotos ao túmulo no cemitério demonstra o simbolismo que este tem no processo de desenvolvimento e afirmação dos santos populares ou milagreiros.

\section{Considerações Finais}

Neste artigo busquei estudar o percurso histórico das devoções a João das Pedras e ao Dr. Olavo Cavalcante Cardoso. Apresentei os elementos que motivaram o surgimento da devoção. Durante a análise da devoção a cada milagreiro apontei os aspectos que distinguiram sua formação e enfoquei os pontos cruciais que unem os dois milagreiros: a morte considerada trágica e o culto desenvolvido no cemitério, junto ao túmulo.

No discurso presente nos jornais impressos e nas entrevistas realizadas sobre o Dr. Olavo Cavalcante Cardoso percebemos o que é abordado para definir a sua imagem de milagreiro. A imprensa abordou em demasia a sua morte, tendo o assassinato do médico "humanitário" merecido grande destaque. O povo retribuiu ao dileto morador, ao exaltar sua bondade e ao estender sua fama de curador e protetor dos pobres. Fatos sempre relatados pelas entrevistas. Entre os mecanismos exteriores que contribuíram para a construção da imagem do Dr. Olavo como milagreiro, o auxílio familiar contribuiu consideravelmente, uma vez que foram os membros da família que auspiciaram a divulgação do "primeiro milagre", a divulgação da fotografia para as mulheres. A família, influente na cidade, também faz parte da organização encarregada de guardar a memória do Dr. Olavo. Uma das atividades desse grupo é publicar todos os anos, no aniversário da morte, um artigo sobre o crime no jornal local A Gazeta do Centro Oeste:

43 anos que, no dia 2 de setembro, Crateús chorou copiosamente a morte de um dos seus filhos mais queridos - o médico Olavo Cavalcante Cardoso. Neste mês de setembro de 2012, 43 anos após o trágico incidente, o túmulo de Dr. Olavo ainda é visitado diariamente. No Dia de Finados, todos os anos, ocorre verdadeira romaria ao seu jazigo. O médico era muito querido e procurado por causa do seu espirito humanitário. Para muitos devotos de sua alma, ele permanece como um santo milagreiro. Na capela de seu túmulo há fotografias de pessoas supostamente curadas pelo médico, além de uma grande lista de nomes, ex-votos, fotografias, bilhetes e cartas com pedidos e com agradecimentos por milagres a ele atribuídos. Com certeza, Olavo goza das glórias eternas, em recompensa pela caridade feita a tantas pessoas humildes em nossa terra. ${ }^{46}$

A memória do Dr. Olavo é sempre propagada através de mecanismos como este do jornal que, de certa forma, oficializa os atributos aferidos ao dileto cidadão de Crateús por

46 "Olavo Cavalcante Cardoso". Gazeta do Centro Oeste. Edição de Setembro de 2012. Publicação online. Disponível em: http://gazetacrateus.com.br/v2010/cultura/crateus-de-ontem-46/. Acesso em: 08/11/2014. 
meio da escrita e da repetição sistemática. Esse processo o reafirma, sobretudo como homem público e como operador de milagres, como milagreiro. Sua imagem e sua memória são mantidas também nas homenagens que lhe são rendidas, atribuindo seu nome a crianças e a lugares públicos.

No dia 15/01/2014 foi inaugurada no bairro Cidade Nova, em Crateús, a Unidade de Pronto Atendimento (UPA) Dr. Olavo Cavalcante Cardoso. Na solenidade, estiveram presentes o prefeito da cidade, Carlos Felipe Beserra, o governador do estado, Cid Gomes, ao lado do Secretário da Saúde do Ceará, Ciro Gomes. ${ }^{47}$ Segundo o jornal, a homenagem se justificava, pois "mesmo após sua morte, Dr. Olavo permanece venerado pela população de Crateús, sendo inclusive atribuídas ao mesmo, várias curas milagrosas". Simbolicamente, o médico estava presente naquele espaço de saúde e doença. Misturava-se, assim, fé na ciência e fé no santo popular. Homenageava-se o milagreiro e o ex-prefeito mais famoso da história da cidade. $^{48}$

Também no caso de João das Pedras, sua morte trágica e seu sofrimento ocupam um lugar de destaque no imaginário popular. Mas, diferentemente do doutor prefeito, sua devoção foi construída de forma "espontânea" pelo povo, que acredita ter o finado se arrependido na hora derradeira. Para os entrevistados, a forma como seu corpo foi carregado, como um porco, até a praça e a carência que marcou seu funeral foram incorporados no testemunho dos devotos como parte do enredo no qual João, o bom ladrão. Para os devotos, ele passou a ser um milagreiro; para os opositores, o defunto que recebe mais visitas no cemitério por curiosidade. O túmulo de João das Pedras é a referência espacial mais visível da devoção no cemitério local. Construído e mantido por iniciativa e fé dos devotos, este espaço consagrou e propagou a imagem do milagreiro, fenômeno muito importante para compreender a religiosidade popular. O túmulo passou por modificações ao longo dos anos, sustentadas unicamente pelos devotos do milagreiro de São Benedito.

Em 2008, o jornal Diário do Nordeste, que circula em todo o Estado do Ceará, publicou uma reportagem sobre João das Pedras, o ladrão que roubava dos ricos para dar aos pobres. Cada mês de novembro o jornal exibia costumeiramente artigos e entrevistas sobre devoções oficiais e não oficiais no estado. Os repórteres chegaram à cidade no dia 02 de novembro de 2008 para registrar o dia mais movimentado da devoção. Segundo o jornalista Wilson Gomes,

Depois de 30 anos desse acontecimento, no dia 2 de novembro, Dia de Finados, o túmulo onde está enterrado João das Pedras, situado no Cemitério de São Benedito, é o mais visitado pela população da cidade e por turistas, alguns, oriundos de cidades vizinhas. Muitos movidos por pura curiosidade, outros pela esperança de um milagre motivada por histórias ouvidas de pessoas que já haviam tido contato anterior com tal devoção. ${ }^{49}$

47 "Dr. Olavo Cardoso, homenageado com nome da UPA/Crateús". 6 de janeiro de 2014. Publicação online. Disponível em: http://www.crateus.ce.gov.br/capa/dr-olavo-cardoso-homenageado-nome-da-upacrateus/. Acesso em: 08/11/2014.

48 Idem.

49 "Curiosidade e busca por um milagre motivam visitas". Diário do Nordeste. Caderno Regional. Matéria publicada em 08/11/2008. Disponível em: http://diariodonordeste.verdesmares.com.br/cadernos/regional/curiosidade-ebusca-por-um-milagre-motivam-visitas-1.449827. Acesso em 8/11/2014. 
Wilson Gomes seguiu reportando suas impressões sobre a devoção:

Numa primeira observação, no Dia de Finados, o que distingue o túmulo de um morto milagroso, ou santo do cemitério, do de qualquer outro morto bem visitado é o número incomum de pessoas que se quedam junto a ele, e o vai-e-vem constante, o dia inteiro, que pode começar já na véspera. A aproximação das pessoas dá-se de maneira variável conforme sejam já devotas, familiarizadas com a existência da devoção ou apenas passantes que lá estão indo pela primeira vez para visitar um finado próximo. Quando alguém narra o milagre, conta sob a forma de testemunho direto, realiza algo mais que apenas comentá-lo ou contálo. A pessoa o sustenta, uma vez que alimenta a fé em sua eficácia e assim concorre para sua reprodução social. ${ }^{50}$

O repórter registrou também alguns testemunhos dos devotos de João das Pedras, pois não existe santo sem devoto. A seguir, seus comentários e parte dos depoimentos.

Os devotos chegam de maneira reservada, discreta, como é o caso da dona-de-casa Maria Mesquita, 56 anos, que desde quando foi visitar pela primeira a sepultura de João das Pedras, nunca mais deixou. "Tive um pedido atendido, então, desde este dia faço questão de vir até aqui visitá-lo. Rezo primeiro para a alma dele, acho que tem momentos que a gente chega a se comunicar", descreve Maria Mesquita.

Teresinha dos Anjos, 67 anos, disse que lembra da morte de João das Pedras. Ela disse que "foi muito triste, era de fazer dó, parte do seu corpo queimado e ainda arrastado. Fiquei muito triste com a morte dele, todos que conheciam sabia que ele roubava, mas roubava dos ricos para os pobres, não era para ele. Na casa do padre João Batista ninguém gosta de ouvir esta história", contou. ${ }^{51}$

Era a primeira vez que a devoção a João das Pedras se propagava em nível estadual e que a memória das peripécias de sua vida e da sua dedicação aos pobres saía do âmbito da oralidade para o da escrita. No caso aqui, para um jornal. O repórter interpelou os devotos sobre sua devoção a um ladrão, buscava achar sentido para uma piedade desse gênero: "Teresinha dos Anjos, 67 anos, disse ao jornal que: Fiquei triste com a morte dele. Todos que conheciam sabia que ele roubava dos ricos para os pobres". ${ }^{52}$ No dia 8 de novembro, quando a publicação foi às bancas, os exemplares em São Benedito esgotaram-se.

De fato, os cemitérios no Ceará refletem as práticas culturais e religiosas dos devotos. A devoção aos milagreiros pode ser acompanhada neste espaço. Os milagreiros são como operadores do direito (advogados) espirituais, sobretudo dos pobres. Assegura-lhes seu direito à saúde, à segurança, à paz, contra a violência, seu direito a recursos para ter o que comer e vestir e um lugar para morar. Os devotos se sentem compreendidos pelos santos e se

\footnotetext{
50 Idem.

51 Idem.

52 "Curiosidade e busca por um milagre motivam visitas". Op. Cit.
} 
identificam com eles. A relação de troca é clara. A cada pedido, uma promessa; a cada pedido atendido, um pagamento de promessa. Os pedidos atendidos são considerados milagres, pois de certa forma para o povo com necessidade essas respostas são sobrenaturais, estavam fora de seu alcance.

Graças à crença em seus milagres, os milagreiros permanecem no imaginário popular como valiosos aliados para a sobrevivência. As devoções crescem e se renovam, o grupo de devotos e as formas de devoção são interpretadas e (re)construídas e o cemitério é o lugar por excelência a partir de onde todos esses processos se dão. Ao analisar o universo da religiosidade popular vivenciada no espaço cemiterial, pude identificar ser este o espaço que conduz os devotos para mais perto de seus intercessores, pois o túmulo é o lugar de onde se avista o milagre e o milagreiro e onde as memórias sobre a vida e a morte dos milagreiros são lembradas, vivenciadas tornando a devoção mais evidenciada. A partir do estudo desses casos, foi possível perceber que a morte para estes sujeitos não significou o fim, mas o início de uma nova trama costurada pela fé nos milagres.

\section{Referências Bibliográficas}

ALVES, Kesia Cristina França. O santo do purgatório. A transformação mítica do cangaceiro Jararaca em herói. (Dissertação de Mestrado). Universidade Federal do Rio Grande do Norte, Natal, 2006.

ANDRADE, Solange Ramos de. A Religiosidade Católica e a Santidade do Mártir. Projeto História, São Paulo, n. 37, p. 237-260, dez. 2008.

ARIĖS, Philippe. História da morte no Ocidente. Rio de Janeiro: Ediouro. 2003. 316p.

BATISTA, Henrique Sérgio de Araújo. Assim na morte como na vida: arte e sociedade no cemitério São João Batista (1866-1915). Dissertação (Mestrado em História). Programa de PósGraduação em História, Universidade Federal do Ceará, Fortaleza, 2003. 202p.

BRANDÃO, Carlos Rodrigues. Os deuses do povo: um estudo sobre a religião popular. São Paulo: Brasiliense, 1980. 250p.

BRANDÃO, José Hudson. São Benedito: dos tabajaras ao terceiro milênio. Fortaleza: Premius; Ed. Livro Técnico, 2002. 521p.

CAVALCANTE, Antonio Mourão e GREENFIELD, Sidney M. Dr. Argeu: a construção de um santo popular. Fortaleza: Editora UFC, 2003. 90p.

CERTEAU, Michel de. A escrita da história. 2ª Ed. Rio de Janeiro: Forense Universitária, 2006. $414 p$.

CORREIA, Iara Toscano. João Relojoeiro: a construção de um santo no imaginário popular Uberlândia/MG (1956-2002). Dissertação (Mestrado em História). Programa de Pós-Graduação em História, Universidade Federal de Uberlândia, Uberlândia, 2003. 246p. 
COSTA, Eden Moraes da. De médico e santo popular: a devoção ao doutor Camilo Salgado em Belém do Pará. Revista Estudos Amazônicos. Belém/PA, v. 5, n. 2, p. 47-73, 2010.

DAVIS, Natalie Zemon. Histórias de Perdão e seus narradores na França do século XVI. São Paulo: Companhia das Letras, 2001. 320p.

DOSSE, François. História e ciências sociais. Bauru: Edusc, 2004. 312p.

FREITAS, Eliane Tânia Martins de. Memória, cultos funerários e canonizações populares em dois cemitérios no Rio Grande do Norte. Tese (Doutorado em Antropologia). Programa de PósGraduação em Ciências Sociais, Universidade Federal do Rio de Janeiro, Rio de Janeiro, 2006. 211p.

FURTADO, Maria Stella. História geral e política de São Benedito. Sobral: Secretaria da Cultura e Turismo, 2005. 438p.

GINZBURG, Carlo. Olhos de madeira: nove reflexões sobre a distância. São Paulo: Companhia das Letras, 2001. 312p.

JURKEVICS, Vera Irene. Os santos da Igreja e os santos do povo: devoções e manifestações de religiosidade popular. Tese (Doutorado em História). Setor de Ciências Humanas Letras e Artes, Universidade Federal do Paraná, Curitiba, 2004. 218p.

LE GOFF, Jacques. História e memória. 5. ed. Campinas: Ed. Unicamp, 2003. 504p.

MAIA, Michelle Ferreira. Lembranças de alguém: a construção das memórias sobre a santidade de João das Pedras. 2008. Dissertação (Mestrado em História). Programa de Pós-Graduação em História Social, Universidade Federal do Ceará, Fortaleza/CE, 2008. 227p.

MAIA, Michelle Ferreira. Lembrança de Alguém: A construção das memórias sobre a santidade de João das Pedras. Fortaleza/CE: Imprensa Universitária: Universidade Federal do Ceará, 2010. $262 p$.

MAIA, Michelle Ferreira. Milagreiros: Um estudo sobre três Santos Populares no Ceará (19291978). Editora Premius: Fortaleza, 2019. 270p.

MENESES, Ulpiano Bezerra de. A História, cativa da memória? Para um mapeamento da memória no campo das Ciências Sociais. Revista do Instituto de Estudos Brasileiros. São Paulo, n. 34, p. 9-24, 1992.

MILLIET, Maria Alice. Tiradentes: O corpo do herói. São Paulo: Martins Fontes, 2001. 294p.

MIRANDA, Aristoteles Guilliod de. Camilo Salgado: o médico e o mito: Notável pelo conhecimento científico, este médico é cultuado como santo popular no Pará. Sintonia. Conselho Regional de Medicina do Estado de São Paulo, n. 35, Abril/Maio/Junho de 2006. Disponível em: https:// www.cremesp.org.br/?siteAcao=Revista\&id=243. Acesso em: 27/11/2019.

OLIVEIRA, Vanessa Souza Eletherio de; CORDEIRO, Rosineide de Lourdes Meira e SILVA, Fernando Leonel da. Morte, cruzes e o bem lembrar no Sertão de Pernambuco. Revista Eletrônica Estácio Recife. v. 4, n. 1, Julho, 2018. Disponível em: https://webcache. googleusercontent.com/search?q=cache:kDOv682hopgJ:https://reer.emnuvens.com.br/ reer/article/download/174/58+\&cd=1\&hl=pt-BR\&ct=clnk\&gl=br. Acessado em: 27/11/2019 
PESAVENTO, Sandra Jatahy. Maria Degolada: A moça alegre que virou santa. In: Sete

Pecados da Capital. São Paulo: Hucitec, p. 345-364, 2008.

PORTELLI, Alessandro. O massacre de Civitella Val di Chiana (Toscana, 29 de junho de 1944). Mito e política, luto e senso comum. In: FERREIRA, Marieta de Moraes e AMADO, Janaína (Coord.). Usos e abusos da História Oral. Rio de Janeiro: Fundação Getúlio Vargas, p. 103-130, 1998

PORTELLI, Alessandro. As fronteiras da memória. O Massacre das Fossas Ardeatinas. História, mito, rituais e símbolos. História e Perspectivas, Uberlândia, n. 25 e 26, p. 9-26, 2002.

QUEIROZ, Maria Isaura Pereira de. Os cangaceiros. São Paulo: Duas Cidades, 1977. 226p.

RAMOS, Francisco Régis Lopes. O verbo encantado: a construção do Pe. Cícero no imaginário dos devotos. ljuí: Ed. Unijuí, 1998. 160p.

SÁEZ, Oscar Calavia. Fantasmas falados: mitos e mortos no campo religioso brasileiro. Campinas: Ed. Unicamp, 1996. 216p.

SCHNEIDER, Marília. Memória e história (Antoninho da Rocha Marmo). São Paulo: T. A. Queiroz, p. 23-87, 2001.

TÁVORA, Franklin. O Cabeleira. Biografia, introdução e notas de M. Cavalcanti Proença. Rio de Janeiro: Ediouro, [s.d.]. 119p.

VALLADARES, Clarival do Padro. Arte e Sociedade nos Cemitérios Brasileiros. Rio de Janeiro: Conselho Federal de Cultura, 1972. 1487p.

VOVELLE, Michel. As Almas do Purgatório ou O trabalho de Luto. São Paulo: Editora Unesp, 2010. 343 p.

Recebido em: 30 de setembro de 2019

Aprovado em: 12 de novembro de 2019 